\title{
Review \\ The Role of Chronic Inflammation in the Development of Breast Cancer
}

\author{
David N. Danforth
}

check for

updates

Citation: Danforth, D.N. The Role of Chronic Inflammation in the Development of Breast Cancer. Cancers 2021, 13, 3918. https:// doi.org/10.3390/cancers13153918

Academic Editor: Christoph F. A. Vogel

Received: 3 May 2021

Accepted: 27 July 2021

Published: 3 August 2021

Publisher's Note: MDPI stays neutral with regard to jurisdictional claims in published maps and institutional affiliations.

Copyright: (C) 2021 by the author. Licensee MDPI, Basel, Switzerland. This article is an open access article distributed under the terms and conditions of the Creative Commons Attribution (CC BY) license (https:// creativecommons.org/licenses/by/ $4.0 /)$.
Surgery Branch, Center for Cancer Research, National Cancer Institute, National Institutes of Health, Bethesda, MD 20892, USA; david_danforth@nih.gov; Tel.: +1-240-760-6213

Simple Summary: Chronic inflammation is an important cause of multiple cancers. While chronic inflammation is present in breast cancer and may influence its outcome, its role in the initiation and development of breast cancer is unclear. A review of the literature was conducted to determine if chronic inflammatory processes are present, both systemically and in normal breast tissue, which may contribute to the development of breast cancer in women. This indicates that several chronic inflammatory factors may influence breast cancer development, with some such as adipose tissue and obesity occurring early in breast carcinogenesis, while others, such as the microbiome and inflammation from genomic changes, may occur with the transition to malignancy. Chronic inflammation appears to be an important risk factor for breast cancer and may influence both the development and conduct of breast cancer.

Abstract: Chronic inflammation contributes to the malignant transformation of several malignancies and is an important component of breast cancer. The role of chronic inflammation in the initiation and development of breast cancer from normal breast tissue, however, is unclear and needs to be clarified. A review of the literature was conducted to define the chronic inflammatory processes in normal breast tissue at risk for breast cancer and in breast cancer, including the role of lymphocyte and macrophage infiltrates, chronic active adipocytes and fibroblasts, and processes that may promote chronic inflammation including the microbiome and factors related to genomic abnormalities and cellular injury. The findings indicate that in healthy normal breast tissue there is systemic evidence to suggest inflammatory changes are present and associated with breast cancer risk, and adipocytes and crown-like structures in normal breast tissue may be associated with chronic inflammatory changes. The microbiome, genomic abnormalities, and cellular changes are present in healthy normal breast tissue, with the potential to elicit inflammatory changes, while infiltrating lymphocytes are uncommon in these tissues. Chronic inflammatory changes occur prominently in breast cancer tissues, with important contributions from tumor-infiltrating lymphocytes and tumor-associated macrophages, cancer-associated adipocytes and crown-like structures, and cancer-associated fibroblasts, while the microbiome and DNA damage may serve to promote inflammatory events. Together, these findings suggest that chronic inflammation may play a role in influencing the initiation, development and conduct of breast cancer, although several chronic inflammatory processes in breast tissue may occur later in breast carcinogenesis.

Keywords: chronic inflammation; normal breast tissue; breast cancer; breast cancer development; obesity; microbiome; sterile inflammation

\section{Introduction}

Chronic inflammation has been recognized to play an important role in cancer since 1863 when Rudolph Virchow noted leucocytes in neoplastic tissues and suggested that the "lymphoreticular infiltrate" reflected the origin of cancer at sites of chronic inflammation [1]. Chronic inflammation is considered to be a contributing factor to the initiation and development of multiple cancers, including colorectal cancer, esophageal cancer, hep- 
atocellular cancer, bladder cancer, gastric cancer, lung cancer, and others (reviewed and references in [2]). A range of etiologies are considered to be responsible for initiating and promoting the chronic inflammation for these cancers, including microorganisms (gastric cancer, colorectal cancer, bladder and hepatocellular cancer), gastric acid, tobacco, alcohol (esophageal cancer), tobacco products (lung cancer), asbestos (mesothelioma), and UV light (melanoma). Breast cancer is the most common malignancy and the second leading cause of cancer death in women in the United States [3]. While the importance of chronic inflammation in the development of other malignancies has been demonstrated, the role of chronic inflammation in the initiation and development of breast cancer is less clear.

There is evidence to indicate that chronic inflammatory changes are associated with breast cancer risk. The C-reactive protein (CRP), an acute phase protein, is considered to be a classic marker for inflammation [4]. CRP has been identified in nipple aspirate fluid (NAF) of healthy women and has been positively related to breast cancer risk as predicted by the Gail model [5]. The administration of anti-inflammatory agents, such as aspirin, to healthy women has been associated with a reduced risk for breast cancer [6]. In addition, crown-like structures, (CLS) a hallmark of chronic inflammation, have been identified in adipose tissue of the breast in obese women and are associated with an increased risk for breast cancer [7]. Normal breast tissue from healthy women also contains multiple immune cells, including CD4+ and CD8+ T lymphocytes, macrophages and dendritic cells, which could potentially mediate chronic inflammatory changes [8]. Together, these findings suggest chronic inflammatory changes may be associated with normal breast tissue and influence the risk for breast cancer.

Chronic inflammation is present in breast cancer and may be associated with multiple cellular changes including tumor infiltrating lymphocytes, tumor associated macrophages, crown-like structures of adipocytes, cancer-associated fibroblasts, and the tumor cells themselves. These chronic inflammatory actions may be triggered by products from microorganisms such as pathogen-associated molecular patterns (PAMPS) in the breast cancer, or cellular products released from injured or necrotic cells, such as damage-associated molecular patterns (DAMPS) and mediated by cytokines and chemokines secreted from associated innate or adaptive immune cells. These chronic inflammatory changes in breast cancer may have important consequences, both locally with tumor promotion and immunosuppression, as well as antitumor and cytotoxicity effects, and on outcome, including survival. Chronic inflammation thus represents an important component of breast cancer and would appear to fulfill many of the criteria to be considered the seventh hallmark of cancer as it is for other malignancies [9]. These observations suggest chronic inflammation may be present throughout breast carcinogenesis and influence multiple points in the initiation, development and behavior of breast cancer. Identification of the presence of these events at different stages of breast carcinogenesis would thus have important implications for both the prevention and treatment of breast cancer.

To address these issues, a review of the literature of chronic inflammatory processes in, or associated with, normal breast tissue and with breast cancer was conducted to clarify the course of chronic inflammation in breast carcinogenesis.

\section{Materials and Methods}

A literature search was conducted through PubMed, Google, and cross-references using the terms "normal breast tissue", "breast cancer", "chronic inflammation", "inflammatory infiltrate", "microbiome", "adipocytes and obesity", "crown-like structures", "cancer-associated adipocytes", "breast fibroblasts", "breast cancer fibroblasts", "mesenchymal stromal cells", "sterile inflammation", "proinflammatory", and "anti-inflammatory" to identify publications describing the nature, distribution and mechanisms of inflammatory characteristics in normal breast tissue and in breast cancer. Normal breast tissue included tissue from biopsy, or reduction mammoplasty specimens, or a prophylactic mastectomy, as well as normal adjacent tissue or contralateral breast tissue in women with breast cancer. Breast cancer tissue included tissue from the breast cancer. Only articles written in English 
were included. Articles were published between 1999 and 2021 and included clinical and laboratory studies as well as selected reviews with expert interpretation and were from peer-reviewed journals. Articles were screened for analysis of the above parameters, relevance to chronic inflammation, risk to breast tissue and prognosis for breast cancer.

\section{Chronic Inflammatory Changes Associated with Normal Breast Tissue}

Normal breast tissue is a complex structure composed of multiple cell types, each with the potential to promote or inhibit chronic inflammation. These cell types include innate and adaptive immune cells (NK cells, CD4+ and CD8+ T cells, $\gamma \delta \mathrm{T}$ cells, macrophages, dendritic cells), adipocytes, fibroblasts, epithelial cells and the microbiome. Each of these cells may play a role in the inflammatory process. In addition, these cells are also in close proximity to regional draining lymph nodes (axillary, internal mammary) where dendritic cells from normal breast tissue may activate, for example, CD4+ cells to generate Th1, Th2, and Th17 cells, which can further influence inflammatory events. Normal breast tissue thus appears to provide the environment for chronic inflammatory changes to influence the development of breast cancer.

\subsection{Evidence of Inflammation Associated with Breast Cancer Risk}

There is evidence, both indirect and direct, that chronic inflammatory changes are associated with an increased risk for breast cancer in women. (A) Indirect studies include those demonstrating inflammatory changes which are reflected in plasma biomarkers such as $\mathrm{C}$-reactive protein (CRP), and studies examining the effect of anti-inflammatory agents such as aspirin on risk for breast cancer. CRP is an acute phase protein considered to be a classic marker for inflammation [4]. A meta-analysis demonstrated that elevated plasma CRP levels were associated with an increased risk for breast cancer (OR, 1.22), with the association strongest in Asian women (OR, 1.57) [10]. Siemes et al. [11] observed high levels ( $>3 \mathrm{mg} / \mathrm{L})$ of plasma CRP were associated with an increased risk of incident cancer (hazard ratio, 1.59-1.68). Obesity is an important risk factor for breast cancer [12-14], and plasma CRP levels are elevated in $7.7 \%$ and $20.2 \%$ of overweight and obese middle-aged women, respectively, compared with $4.8 \%$ in normal weight women [15]. Agnoli et al. [16] examined multiple inflammatory markers in plasma and found high CRP was significantly associated with increased breast cancer risk, and high adiponectin levels with a significantly reduced risk. Among premenopausal women, high TNF- $\alpha$ was associated with significantly increased risk, and high leptin with reduced risk. Additional systemic evidence of chronic inflammatory changes associated with breast cancer is provided by studies of the anti-inflammatory agent aspirin (ASA). When taken regularly, ASA has been shown to reduce the risk for breast cancer in women [17]. A recent meta-analysis suggested that aspirin may reduce the overall risk of breast cancer, reduce the risk of breast cancer in postmenopausal women, hormone-receptor-positive tumors, and in situ breast cancer [17]. Bertrand et al. [18] also reported a benefit of aspirin in ER negative and triple negative breast cancer in African American women. They concluded that the inverse associations of aspirin with ER negative and triple negative disease may therefore be driven by its anti-inflammatory effects rather than hormone-dependent mechanisms. (B) Direct studies include those measuring biomarkers in breast ductal fluid and in breast tissue and their relationship to breast cancer risk. Lithgow et al. [5] studied nipple aspirate fluid (NAF) for the presence of CRP in healthy women aged 30-65 years and found CRP was present and positively related to breast cancer risk as predicted by the Gail model. In that study, the serum CRP was not elevated, and thus the presence of CRP in NAF did not simply reflect its presence systemically but was felt to come from the breast epithelium. The relation between the intraductal levels of CRP in NAF and the 5-year Gail risk scores was considered to reflect a general schema that risk is reflected by an internal state of inflammatory changes in the mammary microenvironment. Hanna et al. [19] examined breast tissue for the presence of inflammatory markers in women with mammographically dense breast tissue, a known risk factor for breast cancer [20]. They found higher expression levels of the 
proinflammatory markers CRP, IL-6, TNF- $\alpha$, and IL-8 were associated with a higher percent mammographic density (PMD) among premenopausal women, and higher expression levels of interleukin 6 were associated with higher PMD among all women $(24.1 \%$ vs. $18.5 \%, p=0.007$ ). Higher expression levels (above median) of the anti-inflammatory marker TGF- $\beta$ were associated with lower PMD among all women and among postmenopausal women. They concluded that these findings constitute further evidence that inflammation plays a role in breast cancer. The proinflammatory gene COX-2, a key driver of chronic inflammation [21], is induced by a variety of inflammatory stimuli, and its expression results in synthesis of prostaglandins with subsequent induction of the inflammatory response. Studies have demonstrated that mammographic breast density is due, in part, to increased deposition of collagen, and COX-2 expression correlates with mammographic density [22]. Collagen deposition in the microenvironment of breast cancer is also significantly associated with high stromal expression of COX-2 and CD163 macrophages [23]. The COX-2 gene and immunoreactive proteins have also been shown to be highly expressed and elevated in adipose tissue (AT) under morbid obesity conditions, another important risk factor for breast cancer [24]. Lastly, a recent study examined the breast ducts of women at normal risk and at high risk for breast cancer by ductal endoscopy. In this study the presence of intraductal fibrous webbing and stranding, an indicator of chronic inflammation, was observed in $40.4 \%$ of the ducts of women at high risk but only $5.4 \%$ of ducts of normal risk women [25]. Together, these findings provide evidence for the association of chronic inflammation in women and the risk for breast cancer.

\subsection{Immune Cells and Inflammatory Cell Infiltrates in Normal Breast Tissue}

Normal breast tissue contains multiple cell types including innate (dendritic cells, macrophages, NK cells) and adaptive (CD4+, CD8+, B cells) immune cells, adipocytes and fibroblasts (Figure 1) [8].

Immune cells are present in breast tissue but do not appear to be infiltrative on the order of inflammatory lymphocyte or macrophage infiltrates such as are seen in breast cancer. Degnim et al. [26] described CD8+, CD11c+, CD45+, and CD68+ cells, with lower densities of CD4+ and $\mathrm{CD} 20+$, which were predominantly localized to the lobules rather than the stroma of normal breast tissue. Ruffell et al. [27] found myeloid-lineage cells including macrophages (CD14 $\left.{ }^{\text {hi }} \mathrm{CD} 11 \mathrm{~b}+\mathrm{HLADR}+\right)$, mast cells (FceR1 $\alpha+\mathrm{CD} 117+\mathrm{CD} 11 \mathrm{~b}-\mathrm{CD} 49 \mathrm{~d}+$ ) and neutrophils $(\mathrm{CD} 15+\mathrm{CD} 11 \mathrm{~b}+\mathrm{CD} 49 \mathrm{~d}-)$ were more evident in normal tissues (both cancer-adjacent and prophylactic mastectomy), which contrasted with that in breast cancer where the density of immune infiltrates was substantially increased and consisted of infiltrates dominated by $\mathrm{T}$ lymphocytes $(\mathrm{CD} 3 \varepsilon+)$, with minor populations of natural killer cells (CD3 $\varepsilon-C D 56+N K G 2 D+)$ and B lymphocytes (CD19/20+HLA-DR+CD3-). Hussein et al. [28] observed lower quantities of CD3+, CD20+, CD68+ and granzyme+ cells in normal breast stroma and parenchyma but substantially increased quantities in breast cancer. They considered the presence of mononuclear inflammatory cell infiltrate in the normal breast tissues to reflect ongoing immune responses against the neoplastic cells. These studies of normal breast tissue, however, did not describe an increase in macrophages, Th1 or Th17 inflammatory CD4+ cells, or other inflammatory markers that might suggest the presence of chronic inflammatory changes. Two other studies have been conducted of benign normal breast conditions, one regarding lobulitis and a second examining benign breast disease. Degnim et al. [26] studied patients with lobulitis and noted significantly higher cell densities of CD4+, CD8+, CD20+, and CD45 cell types in the lobules with lobulitis compared to lobules without lobulitis, while the densities of innate immune cells (monocytes/macrophages and dendritic cells) did not vary significantly with the presence of lobulitis. The authors noted that the immune cell infiltrates of lobulitis were present in the normal condition and that immune infiltrates were not necessarily pathologic but may represent a higher immune cell density present in almost all normal lobules. Degnim et al. [29] also described an immune cell density in patients with benign breast disease (BBD, all of which had evidence of histologic abnormality including proliferative 
changes with or without atypia). They found BBD lobules showed greater densities of CD8+ T cells, CD11c+ dendritic cells, CD20+ B cells, and CD68+ macrophages compared with normal controls. The increased immune cell infiltration observed in BBD tissues relative to normal mammary gland tissue suggested there was a local immune response which may be antigen-specific. The finding that macrophages were more common in lobules of BBD than in normal tissues also suggested greater inflammation in tissues with higher cancer risk. Together, these findings would suggest that tissues with BBD histologic abnormalities, especially proliferative disease, may be accompanied by increased immune cell infiltrates, but that inflammatory infiltrates are otherwise uncommon in normal breast tissue.

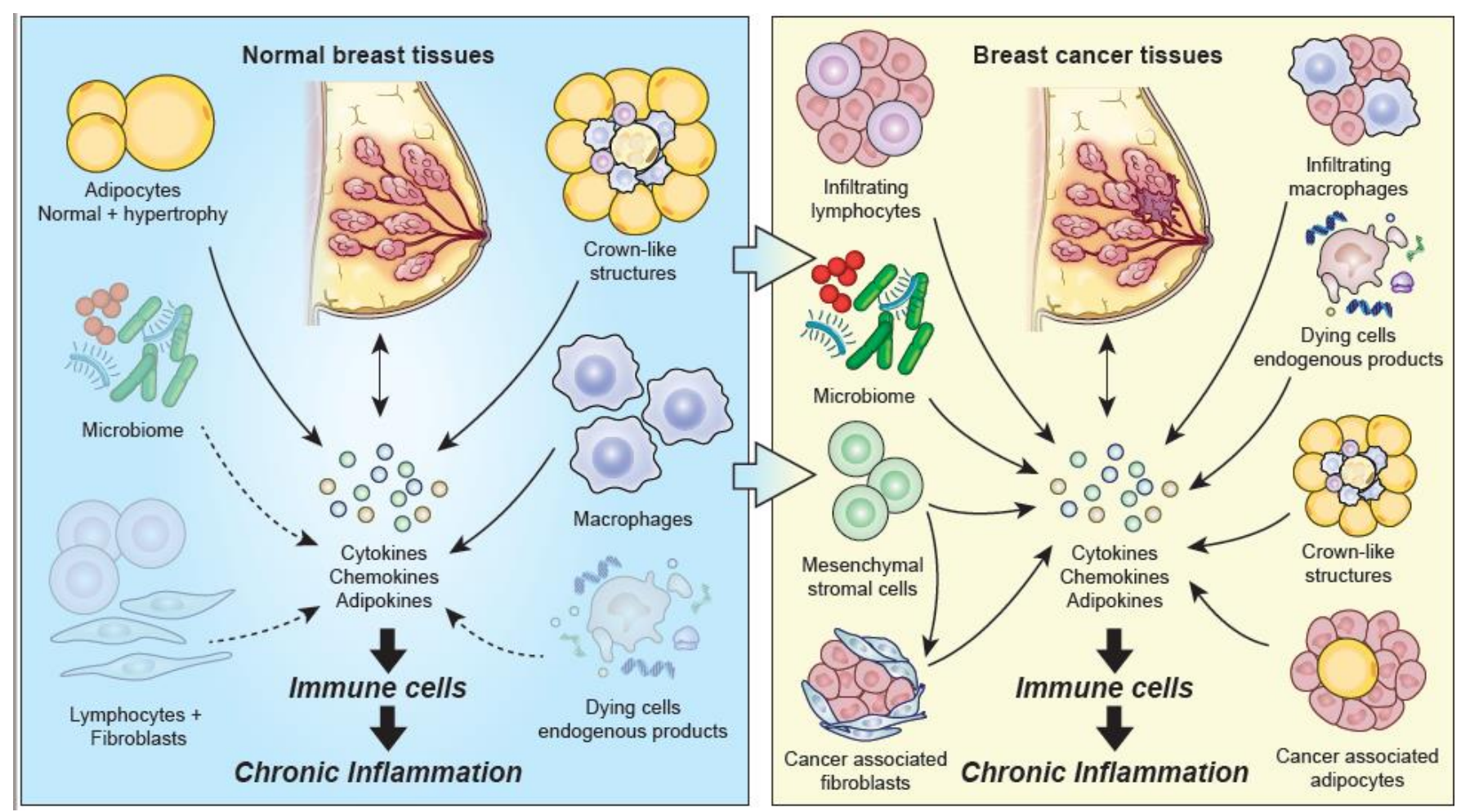

Figure 1. Chronic inflammatory processes in normal breast tissue and breast cancer tissue. Normal Breast tissue (left panel): Chronic inflammation may be initiated in the normal breast from several cell types. Hypertrophied adipocytes and crown-like structures are the most prominent focus and secrete multiple proinflammatory cytokines, including chemokines, and adipokines which promote chronic inflammation. The microbiome, dying or injured cells, and lymphocytes and fibroblasts, are shaded to indicate they are present in normal breast tissue, but their role in promoting chronic inflammation may occur later in breast carcinogenesis. Breast cancer tissue (right panel): Multiple cellular processes are present in breast cancer promoting chronic inflammation. Infiltrating lymphocytes and macrophages, cancer-associated adipocytes and crown-like structures, mesenchymal stem cells and cancer-associated fibroblasts that secrete multiple proinflammatory cytokines, including chemokines and adipokines, while the microbiome and dying or injured cells interact with immune cells through MAMPS and DAMPS to promote chronic inflammation (DN Danforth, original figure).

3.3. Inflammatory Changes of Adipose Tissue Associated with Maintaining Homeostasis and with Breast Cancer Risk

Adipose tissue is a complex structure composed of preadipocytes, adipocytes, macrophages, endothelial cells, fibroblasts and leukocytes [30,31]. White adipose tissue (WAT) is the predominant form in adults and, under normal conditions, serves to maintain homeostasis through secretion of multiple cytokines, adipokines and growth factors, which regulate a wide range of processes including immunity, angiogenesis, glucose and lipid metabolism, fibrinolysis, and body weight homeostasis [31]. These events may include proinflammatory changes involved in proper extracellular matrix remodeling and angiogenesis, two processes known to facilitate adipogenesis in vivo [32]. Adipose 
tissue inflammation under these conditions is considered an adaptive response that enables safe storage of excess nutrients and contributes to a visceral depot barrier that effectively filters gut derived endotoxins [32]. Adipose tissue in the healthy individual also contains several anti-inflammatory mechanisms and adipokines, including adiponectin, C1q/TNFrelated proteins (CTRPs), omentin, and secreted frizzled-related protein 5 (SFRP5) [33]. Adiponectin, for example, abrogates LPS-stimulated TNF production by macrophages, inhibits Toll-like receptor (TLR)-mediated NF- $\mathrm{kB}$ activation in macrophages, and stimulates the production of the anti-inflammatory cytokine IL-10 by human macrophages [34]. Macrophages in lean adipose tissue are primarily M2 macrophages involved in downregulating inflammation and initiating wound repair through the release of anti-inflammatory cytokines such as IL-4, IL-10, IL-13, and TGF $\beta[33,35,36]$. Anatomical studies have shown that the fat volume in the breast may occupy up to $56 \%$ of the total breast volume, providing an important source for local effects of adipose tissue [37].

Adipose tissue can also represent an important source of chronic inflammatory changes associated with increased risk for breast cancer, and these changes may occur in lean as well as overweight or obese tissue. A recent study examined the transcriptome in adipose tissue of the breast in normal healthy women [38]. They found expression of a previously defined active transcriptome phenotype which showed significantly larger adipocytes $(p<0.01)$ than those with the inactive phenotype. Expression of single genes associated with adipocyte activation (leptin, leptin receptor, adiponectin), proinflammatory fat signaling (IKBKG, CCL13), fat remodeling (CAV1, BNIP3), and adipokine growth factors (IGF-1, FGF2) were all significantly elevated in the active samples relative to the inactive samples. The subject population included lean as well as overweight or obese women, however subjects with the active phenotype had no difference in BMI but significantly higher Gail scores (1.46 vs. 1.18; $p=0.007)$. These findings indicated the presence of larger adipocytes, as well as a proinflammatory transcriptome in lean as well as overweight or obese women.

Adipose tissue, as it hypertrophies, secretes inflammatory cytokines and adipokines such as TNF $\alpha$, IL-1, IL-6, IL-8, resistin and leptin, and attracts macrophages with the aid of chemokines including monocyte chemotactic protein (MCP-1), macrophage migration inhibition factor (MIF-1), macrophage inflammatory proteins (MIP- $1 \alpha)$, chemokine CCL5 (RANTES) and others [31,34]. Obesity is associated with local inflammation and macrophage infiltration, with obese women having higher average macrophage counts and inflammatory foci counts than normal-weight women in normal human breast adipose tissues [39]. Resistin, a secretory product of adipocytes, is upregulated in obesity-induced inflammation and induces NF- $\mathrm{KB}$ activity and has proinflammatory and proliferative properties [40]. Leptin, an important secretory product of adipocytes that is increased in obesity, has important proinflammatory actions on the secretion of cytokines (TNF $\alpha$, IL-1, IL-6) and on innate and adaptive immune cells [41]. Adipocytes express a functional and proinflammatory toll-like receptor (TLR) signaling system, which allows for the ability to respond rapidly to acute changes in whole body homeostasis, such as infection [42]. TLRs on adipocytes, including TLR 1, 2, 3, 4, 6, can respond to exogenous products such as lipopolysaccharide (LPS; from bacterial cell walls), stearic acid and palmitic acid to induce proinflammatory cytokine and chemokine release in adipocytes, stimulating the release of TNF- $\alpha$, IL-1 $\beta$, IL-6, IL-8, MCP-1, and resistin by activating the TLR-MD-2-NFkB pathway. Release of free fatty acids from adipocytes following lipolysis, with subsequent binding to TLR4 on macrophages, results in M1 activation of macrophages, which is associated with increased NF- $\mathrm{KB}$ binding activity and aromatase expression and activity $[43,44]$. This functional TLR pathway in adipocytes thus directly connects innate immunity with adipocyte function $[42,45]$. These actions and proinflammatory products are also in close proximity to ductal epithelial cells, and may promote chromosomal instability, increased proliferation, and potentially initiate breast carcinogenesis. Obesity is also characterized by enhanced levels of reactive oxygen or nitrogen species [46], which can cause genotoxic damage to epithelial cells and contribute to progression in the carcinogenic pathway [47]. At the 
same time obesity may also be characterized by a decrease in anti-inflammatory factors such as adiponectin, CTRP12 (Adipolin), omentin, and Sfrp5 [30,33]. Collectively, these anti-inflammatory factors normally act to block NF-kB activation and reduce cytokines $\mathrm{TNF} \alpha$, IL-6 and IL-18 [33], decrease macrophage accumulation and proinflammatory gene expression [48], inhibit TNF $\alpha$-induced vascular inflammation [33,49], and control inflammatory cells within adipose tissue [50]. The proinflammatory changes have been well summarized by Van Kruijsdijk et al. [51] who observed that obesity is strongly associated with changes in the physiological function of adipose tissue, increased levels of leptin, plasminogen activator inhibitor-1, endogenous sex steroids, and chronic inflammation, which are involved in carcinogenesis and cancer progression.

Crown-like structures (CLS), a hallmark of chronic inflammation, may be present in normal breast tissue. A very nice study by Carter et al. [7], demonstrated that the incidence of CLS in breast tissue is related primarily to the presence or absence of benign breast disease (BBD) histologic changes (nonproliferative or proliferative changes). In the absence of BBD (or breast cancer), CLSs in the breast tissue of either lean or obese women are rare (incidence $0.0 \%$ and $6.3 \%$, respectively; Table 1 ).

Table 1. Incidence of crown-like structures in breast adipose tissue according to body weight status.

\begin{tabular}{|c|c|c|c|c|c|c|c|}
\hline \multicolumn{8}{|c|}{ Normal Breast Tissue } \\
\hline Lean, (BMI < 25) & $\begin{array}{c}\text { Overweight } \\
\text { (BMI 25-29.9) }\end{array}$ & Obese & $\begin{array}{c}\text { BBD } \\
\text { BMI }<30 \text { Controls }{ }^{2}\end{array}$ & $\begin{array}{c}\text { BBD } \\
\text { BMI }<30 \text { Cases }^{3}\end{array}$ & $\begin{array}{c}\text { BBD } \\
\text { Obese Controls }^{2}\end{array}$ & $\begin{array}{c}\text { BBD } \\
\text { Obese Cases }^{3}\end{array}$ & References \\
\hline $0.0 \%^{1}$ & $3.3 \%^{1}$ & $6.3 \%^{1}$ & $6.3-8.0 \%$ & $13.3-24.2 \%$ & $45.8 \%$ & $45.0 \%$ & [7] \\
\hline \multicolumn{8}{|c|}{ Breast Cancer Tissues } \\
\hline $17 \%$ & & $54 \%$ & & & & & [52] \\
\hline $34 \%$ & $53 \%$ & $90 \%$ & & & & & [53] \\
\hline \multirow[t]{2}{*}{$8 \%$} & $70 \%$ & $75 \%$ & & & & & [43] \\
\hline & $57.0 \%{ }^{4}$ & & & & & & {$[54]$} \\
\hline $24 \%$ & $34 \%$ & $\begin{array}{l}57 \%^{5} \\
65 \%^{6}\end{array}$ & & & & & [55] \\
\hline $34.8 \%$ & $50 \%$ & $100 \%$ & & & & & [56] \\
\hline
\end{tabular}

${ }^{1}$ Komen Tissue Bank; ${ }^{2}$ BBD—breast tissue with benign breast disease, Control—no future breast cancer; ${ }^{3}$ BBD, Cases—future breast cancer; ${ }^{4}$ Median BMI 25.7. ${ }^{5}$ Obesity, $30-35 \mathrm{~kg} / \mathrm{m}^{2} ;{ }^{6}$ Obesity $\geq 35.0 \mathrm{~kg} / \mathrm{m}^{2}$.

In the presence of $\mathrm{BBD}$ in normal breast tissue, CLSs are increased with increasing BMI (incidence $=13.3-24.2 \%$ at BMI $<30$, and $45.8 \%$ in obese women), but are independent of age [7]. These data suggest that CLS-B (CLS of breast)-associated adipose tissue inflammation occurs in a significant subset of individuals with BBD, and that BBD stromal tissues are far more frequently inflamed than donor (lean) breast tissues [7]. These authors previously reported that lobules of BBD tissues had a significantly higher density of CD68-positive macrophages compared with lean individuals [29], supporting the hypothesis that BBD is associated with an epithelial and stromal chronic inflammatory environment. Importantly, high CLS-B densities were found to be independently associated with an increased breast cancer risk. Among BBD biopsies, a high CLS-B count ( $>5$ CLS-B/sample) conferred a breast cancer OR of 6.8 (95\% CI, 1.4-32.4), $p=0.02$ [7].

Analyses of the stromal vascular and adipocyte fractions of the mammary gland have also suggested that macrophage-derived proinflammatory mediators induce aromatase and estrogen-dependent gene expression (PR, pS2) in adipocytes. The presence of CLS in breast tissue, and saturated fatty acids which have been linked to obesityrelated inflammation, have been shown to stimulate NF- $\mathrm{kB}$ activity in macrophages leading to increased levels of TNF- $\alpha$, IL- $1 \beta$, and Cox-2, each of which contributed to the induction of aromatase in preadipocytes [57]. This process has been referred to as the obesity $\rightarrow$ inflammation $\rightarrow$ aromatase axis [57]. Aromatase functions to convert androgens to estrogens, and elevated levels of aromatase expression and activity could contribute to the increased incidence of hormone-receptor positive breast cancer in obese postmenopausal 
women, thus representing another important consequence of chronic inflammatory changes in breast tissue.

\subsection{Fibroblasts in Normal Breast Tissue}

In normal breast tissue fibroblasts are a major component of the extracellular matrix (ECM) and serve to produce collagens, reticular fibers and other components of the extracellular matrix. The stroma of the normal breast differs significantly from the stroma of breast cancer, containing sparse connective tissue surrounding the duct compared with abundant connective tissue in carcinoma [58]. There is a strong interaction between fibroblasts and epithelial cells which may be involved in carcinoma initiation and promotion, including secretion of the fibroblast growth factor (FGF) family, the IGF family, the EGF family, hepatocyte growth factor (HGF), and the TGF- $\beta$ family [58]. Most of these factors are predominantly stimulators of proliferation and can play a role in promoting the carcinogenic process, whereas TGF $\beta$ is a growth inhibitor of breast epithelial cells [58]. The role of fibroblasts in chronic inflammation in normal breast tissue, however, is unclear. Parsonage et al. [59] described a Stromal Access Code consisting of multiple components including CXCL12, CXCL13, CCL19, CCL21, adhesion molecules, cytokines IL-6, IL-7, and fibroblast growth factors-7 (FGF-7, FGF-10), which have been shown to act to regulate leucocyte accumulation, differentiation, and survival in several stromal niches (bone marrow, thymus, lymph node). The aberrant expression of components of this code contributes to the persistence of chronic inflammatory disease at these sites [59]. It has also been reported that fibroblasts in hyperplastic or dysplastic skin lesions may contain a proinflammatory gene signature [60], including expression of chemokines and interleukins and which may be involved in early carcinogenesis $[60,61]$. These studies suggest a potentially important role for fibroblasts in chronic inflammation. Whether expression of this signature or the signal address code occurs in, for example, hyperplastic but otherwise normal breast tissue, is not known, but in view of the importance of fibroblasts to breast tissue structure and function, this would be an important question for future studies.

\subsection{Potential Contributors to Chronic Inflammation in Normal Breast Tissue}

In addition to the cellular components, there are other factors which may contribute to inflammation in normal breast tissue such as the microbiome and cellular substances released from injured or dying cells. Both of these factors are present in breast cancer tissues and play a role in promoting the chronic inflammatory changes in these tumors (see breast cancer discussion below). As a whole, the breast is a favorable environment for the growth of bacteria, as it is made up of fatty tissue with extensive vasculature and lymphatic drainage [62]. Healthy normal breast tissue contains a prominent microbiome [63-65]. The inflammatory changes associated with the microbiome in these tissues appear to serve primarily to maintain homeostasis. Commensal bacteria in healthy normal breast tissue are considered to play an important role in nutritive, immune-modulating and metabolic contributions for the maintenance of health $[62,66]$. Bacteria may maintain the healthy status of breast tissue by stimulating host inflammatory responses [62,67]. These bacteria and their metabolites can interact with TLRs of the innate immune system to trigger inflammatory signaling pathways to promote tissue repair and regeneration, and help maintain homeostasis [68], as well as limit or inhibit chronic inflammatory actions [69]. Macrophage activation may also result in secretion of a number of endogenous anti-inflammatory mediators including the cytokines IL-4, IL-10, IL-13, TGF- $\beta$, VEGF, and lipid mediators $[35,70]$. Chan et al. [71] has proposed that certain microbes might play a preventative role in breast carcinogenesis by affecting levels of estrogen or by promoting antitumor immunity and immune surveillance. Urbaniak et al. [72] observed that Lactococccus and Streptococcus were more prevalent in healthy women than in breast cancer patients. Both exhibit anticarcinogenic properties and may play a role in prevention. Lactococcus lactis can activate NK cells to produce IFN- $\gamma$ which subsequently activates dendritic cells and macrophages, and production of the anti-inflammatory cytokine IL-10 [73]. 
De Moreno et al. [74] has also demonstrated that Lactobacillus helveticus stimulates production of the anti-inflammatory cytokines IL-4 and IL-10 (mediators of the anti-inflammatory macrophages M2) and decreases production of IL- 6 . At the same time, studies have compared normal cancer-adjacent breast tissue with healthy normal breast tissue and observed a prominent difference in the microbiome content $[64,65,72]$. The cancer-adjacent breast tissue microbiome is considered dysbiotic, with the potential to influence breast carcinogenesis. Interestingly, the genera Fusobacterium has been demonstrated in healthy normal breast tissue and was more abundant in the normal cancer-adjacent breast tissue $[64,65,72]$. The Fusobacterium genus may release factors and provide a proinflammatory environment, which leads to carcinogenesis [75]. This would indicate a potential source of chronic inflammatory events in healthy normal tissue. It is also important to note that studies have demonstrated that consumption of a Western or Mediterranean diet modulated mammary gland microbiota and metabolite profiles, and thus directly influenced microbiome populations in the mammary gland [76]. This would suggest that the composition of the microbiome in healthy normal breast tissue may be dynamic and vary according to dietary changes. At the same time, it is recognized that studies examining healthy normal breast tissue (or cancer-adjacent breast tissue) for the presence of chronic inflammatory changes associated with the microbiome have not been described, raising the possibility that these changes may occur later with the transition to malignancy.

The initiation of sterile inflammation by release of endogenous products from injured or dying cells is an important potential source of chronic inflammation, and there is evidence this process may occur in healthy normal breast tissue. Damaged or dead cells may release a range of endogenous substances (alarmins) including proteins and peptides, polysaccharides and proteoglycan, nucleic acids and phospholipids, which in turn may interact with TLRs on immune cells to regulate many sterile inflammatory processes [77]. A very interesting earlier study examined the morphological identification of cell multiplication (mitosis) and cell deletion (apoptosis) within the lobules of the "resting" human breast during the menstrual cycle [78]. They found that responses-mitosis and apoptosis-had a biorhythm in phase with the menstrual cycle, with a 3-day separation of the mitotic and apoptotic peaks. Both processes showed significant cyclical variation $(p<0.0001)$ with the peak of mitosis occurring at Day 25, and that for apoptosis occurring at Day 28. The 3-day separation of the peak in events was statistically significant. The study did not find significant differences in the responses between groups according to parity, contraceptive-pill use or presence of fibroadenoma. Of note, a recent study has shown that the high mobility group box 1 protein (HMGB1), an important endogenous protein [77], is released extracellularly during apoptotic cell death [79]. HMGB1 also has the potential to interact with several TLRs and induced sterile inflammation [77]. These findings provide a potential link between cellular activities and the initiation of inflammation in the resting breast, especially one which may occur early in breast carcinogenesis. In addition, normal breast cells contain a range of genomic changes [80], and damaged human cells can develop persistent chromatin lesions bearing hallmarks of DNA double-strand breaks (DSBs) which may initiate increased secretion of inflammatory cytokines such as interleukin-6 (IL-6) [81]. Sterile inflammation may thus be an important but less recognized source of inflammation in the healthy breast. Further studies are needed to define the presence and nature of inflammatory changes associated with these processes in normal breast tissue.

Lastly, there exists a variety of benign inflammatory conditions of the breast (mastitis), either infectious or noninfectious, which may, or may not, contribute to the chronic inflammation of breast carcinogenesis [82]. Some are more common (lactational mastitis, breast abscess, fibrocystic disease) than others (plasma cell mastitis, diabetic mastopathy). The significance of chronic inflammatory changes in these lesions is not clear. Some would be considered in the category of BBD described by Degnim et al. [83] (fibrocystic disease and ductal hyperplasia with/without atypia) and might have associated chronic inflammatory changes. Other inflammatory conditions, such as lactational mastitis or chronic granulo- 
matous disease, are not generally considered to be associated with an increased risk for breast cancer.

\section{Chronic Inflammatory Changes Associated with Breast Cancer}

\subsection{Chronic Inflammatory Cell Infiltrates in Breast Cancer Tissues}

Breast cancer contains a prominent chronic inflammatory component consisting of cells of the immune system (lymphocytes, macrophages, dendritic cells, monocytes, neutrophils) as well as cancer-associated adipocytes, crown-like structures of adipocytes, and cancerassociated fibroblasts (Figure 1). Inflammatory cell infiltrates consisting of lymphocytes (CD4+ and CD8+ T cells and B+ cells) and macrophages are a common feature of breast cancer (Table 2; $[27,84])$.

Table 2. Cellular proinflammatory and anti-inflammatory substances.

\begin{tabular}{|c|c|c|c|}
\hline Cell Type & $\begin{array}{l}\text { Proinflammatory Cytokines, } \\
\text { Chemokines, Growth Factors }\end{array}$ & $\begin{array}{l}\text { Anti-Inflammatory Cytokines, } \\
\text { Chemokines, Growth Factors }\end{array}$ & References \\
\hline Infiltrating lymphocytes & $\begin{array}{l}\text { Cytokines IL-2, TNF } \alpha \text {, and INF } \gamma \text { as well, } \\
\text { IL-17, IL-21 and IL-22. }\end{array}$ & & {$[85,86]$} \\
\hline Adipocyte & $\begin{array}{c}\text { IL-1 } \beta, \text { IL-6, TNF- } \alpha \text {, resistin, leptin, } \\
\text { MCP-1, CCL2, CXCL8, CXCL1, CXCL10 }\end{array}$ & $\begin{array}{c}\text { Adiponectin, CTRPs, SFRP5, } \\
\text { omentin, TGF } \beta\end{array}$ & {$[31,33,34,87]$} \\
\hline Adipocyte in obesity & $\begin{array}{l}\text { TNF, IL-1 } \beta \text {, IL-6, IL-12, IL-17, IL-18, } \\
\text { IFN- } \gamma \text {, resistin and leptin, RBP4, lipocalin } \\
2, \text { CCL2, CCL5, CXCL5, MCP-1, MIP-1 } \alpha \text { ) }\end{array}$ & $\begin{array}{l}\text { Adiponectin, CTRPs, Omentin, } \\
\text { SFRP5, IL-10 }\end{array}$ & {$[31,33,88-90]$} \\
\hline Crown-like structures & TNF, IL-1 $\beta$, IL-6, and leptin, CCL2 & & {$[33,91]$} \\
\hline Cancer associated adipocyte & $\begin{array}{l}\text { Chemokines CCL2 and CCL5, IL-1 } \beta \text {, IL-6, } \\
\text { TNF- } \alpha, \text { VEGF, leptin }\end{array}$ & Adiponectin & [92-94] \\
\hline Microbiome & MAMPS, PAMPS, microbial metabolites & $\begin{array}{c}\text { Short-chain fatty acids, IL-10, } \\
\text { TGF } \beta\end{array}$ & {$[70,95,96]$} \\
\hline M1 macrophages & $\begin{array}{c}\text { TNF } \alpha \text {, IL-1, IL-6, IL-12, IL-23, CXCL9, } \\
\text { CXCL10, ROS, RNS }\end{array}$ & & {$[35,97,98]$} \\
\hline M2 macrophages & & $\begin{array}{l}\text { IL-4, IL-10, IL-13, TGF } \beta \text {, VEGF, } \\
\text { EGF }\end{array}$ & {$[35,98]$} \\
\hline Mesenchymal stem cells & $\begin{array}{l}\text { MIP-1a and MIP-1b, RANTES, CXCL9, } \\
\text { CXCL10, CXCL11 }\end{array}$ & $\begin{array}{l}\text { IL-6, HGF, TGF } \beta, \text { IL-1RA, PGE2, } \\
\text { Galectin-1, IDO, NO, PDL-1 }\end{array}$ & [99-101] \\
\hline Fibroblasts & FGF, IGF, EGF, HGF, TGF- $\beta$ family & & [58] \\
\hline Cancer-associated fibroblasts & $\begin{array}{c}\text { IL-1, IL-6, IL-8, IL-10, TNF } \alpha, \text { CXCL1, } \\
\text { CXCL2, CXCL5, CXCL12, CCL2, CCL5, } \\
\text { COX2 }\end{array}$ & & {$[60,102-104]$} \\
\hline Dying/Injured cells & $\begin{array}{c}\text { Endogenous agents including proteins } \\
\text { and peptides, polysaccharides and } \\
\text { proteoglycans, nucleic acids, } \\
\text { phospholipids, or small organic } \\
\text { molecules. }\end{array}$ & & {$[77,105-107]$} \\
\hline
\end{tabular}

RBP-4—retinol binding protein; CTRPs-C1q/TNF-related proteins; SFRP5—secreted frizzled-related protein5; MCP-1—monocyte chemoattractant protein-1; IDO—indoleamine 2,3-dioxygenase; IL-1RA-IL-1 receptor antagonist; NO—nitric oxide; MIP-1 $\alpha$-macrophage inflammatory proteins; FGF-fibroblast growth factor; IGF-insulin-like growth factor; EGF—epidermal growth factor; HGF-hepatocyte growth factor; PGE2-prostaglandin $\mathrm{E}_{2}$; MAMPS - microbe associated-molecular patterns; PAMPS - pathogen-associated-molecular patterns; ROS-reactive oxygen species; RNS-reactive nitrogen species.

Mohammed et al. [84], for example, observed that $91 \%$ of patients with invasive ductal carcinoma had high grade inflammatory immune cell infiltrates, with tumor lymphocytic infiltrate, macrophage infiltrate, CD8+ T-lymphocytic infiltrate, and B-lymphocytic infiltrate independently associated with cancer survival. Others [28] have found the inflammatory infiltrate to be primarily in the stroma, and to consist of $\mathrm{CD} 3+$ cells reflecting increased 
T cell proliferation. Ruffell et al. [27] also described a prominent immune cell infiltrate in breast cancer and dominated by T lymphocytes $(\mathrm{CD} 3 \varepsilon+)$, with minor populations of natural killer cells and B cells. They noted a shift within tumors toward a TH2-type response in BC characterized by increased presence of $B$ cells and $C D 4+T$ cells, in comparison with normal breast tissue. Activated dendritic cells may translocate bacterial antigens to regional lymph nodes to promote the activation of adaptive CD4+ T cells to Th1, and Th17 with associated inflammatory functions [108]. Secretion of IFN- $\gamma$ and TNF $\alpha$ by Th1 cells may activate proinflammatory M1 macrophages [109]. Th17 cells may constitute up to $29.3 \%$ of breast cancer infiltrating lymphocytes in some patients [110]. Th17 produces cytokines IL-17, IL-21 and IL-22 [85]. The inflammatory cytokine IL-17A, for example, binds to breast cancer cells and activates oncogenic ERK and NF- $\mathrm{KB}$ pathways, and can bind to fibroblasts and activate NF- $\mathrm{KB}$ and STAT3 pathways leading to production of IL-6 and G-CSF. IL-6, in combination with TGF $\beta$, further activates Th17 cells leading to a chronic inflammatory state and amplification of IL-17A signaling [111]. IL-17 and IL-21 may also serve to recruit polymorphonuclear lymphocytes. Interestingly, Eftekhari et al. [112] recently observed that Th1 and Th17 expression was reduced in breast cancer compared with healthy normal breast tissue, suggesting these cell types may also play a role in tumor rejection. CD8+ T cells in breast cancer are predominantly of the effector memory cell subtype, with cytotoxic capacity mediating antitumor immunity, but with the ability to secrete proinflammatory cytokines IL-2, TNF $\alpha$, and INF $\gamma$ as well $[86,113]$. Chronically activated B cells promote accumulation of innate cells in the neoplastic stroma by immunoglobulin and cytokine production [114]. Together, these proinflammatory mediators may have an important influence on all phases of breast carcinogenesis, including potentiation, tumor cell proliferation, transformation, invasion and metastasis [115].

Macrophages play an important role in chronic inflammation in breast cancer. Tumorassociated macrophages (TAMs) are among the most common cells in the leucocyte infiltrate and may constitute over $50 \%$ of the number of cells within the tumor [109]. Macrophages may be present as the classically activated M1 phenotype or the alternatively activated M2 phenotype; however, there is evidence that macrophages exhibit different phenotypes during different stages of tumor initiation and progression. During early stages of transformation, recently recruited macrophages are exposed to a wide variety of proinflammatory signals derived from the epithelial cells and the surrounding stroma, and often express M1-related factors that have protumorigenic properties, such as IL-1 $\beta$ and IL-6 [116]. M1 macrophages exhibit potent microbicidal and tumoricidal activity by releasing proinflammatory cytokines (such as TNF, IL-1, IL-6, IL-12, IL-23), promoting strong proinflammatory Th1 immune responses and exerting antiproliferative and cytotoxic activities, which result from the release of reactive oxygen species (ROS) and reactive nitrogen species (RNS) [35]. $\mathrm{TNF} \alpha$ has been shown to be increased in breast cancer compared with healthy normal breast tissue [112]. In established, progressive breast cancers, IL-4 and IL-13 derived from Th2 cells elicit alternative M2 activation of TAMs [117], with production of immunosuppressive factors such as IL-10 and TGF- $\beta$ that are capable of actively suppressing the antitumor immune response [116]. Most TAMs in the tumor microenvironment are closely related to the M2-like phenotype [118]. Chemokines, including CC chemokines, are major determinants of macrophage and lymphocyte infiltration in carcinoma of the breast [1].

Interestingly, several studies have demonstrated an increase in inflammatory infiltrates in the subtype hormone receptor-negative breast cancer, including high lymphocytic infiltrate, plasma cell infiltrate, other inflammatory cell infiltrate and macrophage infiltrate associated with ER neg/PR neg tumors [84], higher numbers of peri- and paratumoral tumor infiltrating B lymphocytes associated significantly with hormone receptor (ER/PR) negative $(p=0.008)$ and HER2 + status [119], and high granulin expressing bone marrow cells recruited to breast cancer expression and correlated with the most aggressive triplenegative, basal-like tumor subtype [120]. On the other hand, serum CRP, a marker of chronic inflammation, appears to be independent of tumor subtype, with elevations in receptor-positive as well as receptor-negative tumors [121-124]. 


\subsection{Potential Contributors to Chronic Inflammation in Breast Cancer}

Breast cancer contains a prominent microbiome which is considered dysbiotic and with the potential to influence breast carcinogenesis [67]. Microbiota may trigger inflammation through release of a variety of substances (MAMPS or PAMPS, such as dsRNA, LPS and lipopeptides) which react with pattern recognition receptors (PRRs) on innate immune cells [70,95]. Engagement of the PRRs on macrophages, for example, activates the macrophage to the M1 subtype, triggering signaling pathways that lead to the release of the inflammatory cytokines TNF $\alpha$, IL-1, IL-12, IL-23 (Table $2[35,108]$ ), chemokines and the recruitment and activation of lymphocytes, with the propagation of chronic inflammation $[35,70,108]$. Bacterial antigen activation of CD4+ lymphocytes to Th1, Th2, and Th17 cells was described above. It has recently been shown, for example, that microbially driven TLR5-dependent IL-6 signaling promotes breast cancer malignant progression through tumor-promoting inflammation [125]. Li et al. [126] demonstrated that lipopolysaccharide (LPS), a major structural component of Gram-negative bacteria and a potent inducer of inflammation, promoted pulmonary metastases from breast cancer in an animal model.

Immune cells may also respond to endogenous ligands released from cells as a result of cell stress, injury or cell death, through a process called sterile inflammation $[105,127,128]$. Cell stress may result from genomic instability from mutational changes, inherited genomic changes and increased proliferation, as well as metabolic, hypoxic, or mechanical stress, including environmental carcinogens [128]. The DAMPS may be released by a variety of cells, although the majority of endogenous ligands appear to be extracellular matrix components generated as a result of tissue injury [77]. Many of the PRRs activate a shared set of inflammatory pathways, including NF- $\mathrm{KB}, \mathrm{p} 38$, ERK, inflammasome assembly and IL$1 \beta$ and IL-18 release, as well as secretion of IL-6, TNF, LT- $\beta$, IFN $\gamma$ and TGF- $\beta$, and promote the recruitment of inflammatory cells [106]. A pathway for the activation of tumor antigenspecific T-cell immunity that involves secretion of the high-mobility-group box 1 (HMGB1) alarmin protein by dying tumor cells, and its action on Toll-like receptor 4 (TLR4) expressed by dendritic cells (DCs), has recently been described in breast cancer [129]. This pathway may also play an important role in the response to radiotherapy and chemotherapy. At the same time, while there are multiple proinflammatory events induced by factors released from dying cells, there is also evidence these events may be tempered to some degree by DAMPS released from these cells which are anti-inflammatory, reducing expression of cytokines IFN- $\beta$, IL- 6 and IL-12 [130]. Multiple endogenous inhibitors of the proinflammatory transcription factor NF- $\mathrm{kB}$ have also been identified [131].

\subsection{Cancer-Associated Adipocytes and Crown-Like Structures}

Adipocytes constitute the main cellular component of the extracellular matrix in breast cancer [132]. These adipocytes, referred to as cancer-associated adipocytes (CAAs), are in close proximity to cancer cells and are morphologically and phenotypically distinct from adipocytes of normal breast tissue [132]. Adipocytes in breast cancer undergo reprograming, which involves the metabolic regulation of almost all macronutrients, such as carbohydrates, lipids, and amino acids [92]. CAAs secrete inflammatory factors that modify the behavior of breast cancer cells, including greater secretion (compared to normal adipocytes) of chemokines CCL2, and CCL5, interleukin-1 $\beta$ (IL-1 $\beta$ ), interleukin-6 (IL-6), tumor necrosis factor-alpha (TNF- $\alpha$ ), vascular endothelial growth factor (VEGF), leptin, adiponectin and IGF-1 [92]. The high CAA intratumoral adipocyte content has been shown to be enriched in inflammation-related gene sets such as TNF- $\alpha$ signaling via NF-kB, IL-6/JAK/STAT3 signaling and inflammatory response, and thus a high amount of intratumoral adipokines associated with inflammation that promote angiogenesis, invasion, metastases, and tumor progression [93]. At the same time, a high intratumoral adipocyte count may also be associated with less unfavorable immune cells including less type 2 helper T cells (Th2), regulatory T cells (Treg), and M2 macrophages (M2), especially in the ER+/Her2-subtype, suggesting a more favorable immune response [93]. This suggests that intratumoral adipocytes may contribute to breast cancer through inflammation, metastasis, 
and cancer stemness, but may also be associated with a favorable immune response that slows the cancer aggressiveness down, particularly in this subtype [93].

Macrophages recruited to adipose tissue bind to the adipocytes of dying cells at the CCR2 receptor to form crown-like structures (CLS) [7]. CLSs composed of macrophages (typically proinflammatory M1 type) are a histologic hallmark of the proinflammatory process and may be present in the adipose tissue near the breast cancer. Tumor-associated macrophages (TAMS) and CLS are more frequent in adipose tissue of breast cancer than normal (reduction mammoplasty) adipose tissue, and in breast cancer are more frequent in breast tissue of obese than of lean women (Table 1). Interestingly, whereas CLSs are rare in normal lean women, they are present in lean women with breast cancer (incidence $8.0-34.8 \%$; Table 1). The finding of CLS in lean individuals indicates a subset of lean individuals that are known to be metabolically unhealthy [53]. Release of proinflammatory mediators, including TNF- $\alpha$, IL-1, IL-6, and cyclooxygenase-2 (COX-2)-derived prostaglandin E2 (PGE2), contribute to the chronic inflammatory state and may also act to upregulate the transcription of the CYP19 gene encoding aromatase, leading to estrogen production [57]. Proinflammatory macrophages might also promote malignant transformation through release of mutagenic reactive oxygen and reactive nitrogen species. TAMs and CLS contribute to the increased risk and worse prognosis of breast cancer. High levels of CD163+ macrophages were associated with shorter disease-free survival in node-negative breast cancer patients $(p=0.033)$, and CD68+ CLSs were associated with shorter overall survival in node-positive breast cancer patients $(p=0.015)$ [133]. It has also recently been shown that breast cancers from black patients contain significantly higher densities of TAMs and CLS compared with non-black Latinas and Caucasian women [134]. However, whether and how immune inflammatory components in the tumor microenvironment (TME) may correlate with the aggressiveness of breast cancer in AA women remains unclear and is an important topic for future studies [134].

\subsection{Mesenchymal Stromal Cells (MSCs) and Cancer-Associated Fibroblasts}

Mesenchymal stromal cells (MSCs) are adult, fibroblast-like multipotent cells characterized by the ability to differentiate into tissues of mesodermal origin, such as adipocytes, chondroblasts, osteoblasts [99], and, importantly, into cancer-associated fibroblasts [135]. MSC may arise from a variety of sites, including adipose tissue, skin, tendon, muscle, dental pulp and others $[99,136]$. MSC niches respond to numerous signals generated by the tumor milieu, including TGF- $\beta$, IL-6, Cyclophilin B, HDGF, uPA/uPAR, MCP-1, VEGF and FGF2, which can act as chemoattractants for MSCs [137]. At the tumor site, MSCs infiltrate into the stroma and produce bioactive molecules such as CCL5, IL-6, SDF-1 and TGF $\beta$, which promote tumor growth and/or distant metastasis to secondary organs, such as the lungs [137]. Within the tumor, the behavior of MSC may be determined by the inflammatory nature of the environment. As nicely summarized by Bernado et al. [99], in the absence of an inflammatory environment (low levels of TNF $\alpha$ and IFN $\gamma$ ), MSCs may adopt a proinflammatory phenotype (MSC1) and enhance T cell responses by secreting chemokines that recruit lymphocytes to sites of inflammation (e.g., MIP-1a and MIP-1b, RANTES, CXCL9, CXCL10, and CXCL11) [100,138]. Polarization to a proinflammatory MSC1 phenotype can also be influenced by activation of TLR4 by low levels of lipopolysaccharide (LPS) derived from Gram-negative bacteria, suggesting an important interaction with microbia in breast tissue [99]. In the presence of an inflammatory environment (high levels of TNF $\alpha$ and IFN $\gamma$ ), MSCs become activated and adopt an immune-suppressive phenotype (MSC2) by secreting high levels of soluble factors, including IDO, PGE2, NO, TGF $\beta$, Hepatocyte Growth Factor (HGF) and hemoxygenase (HO), that suppress T cell proliferation $[99,101]$. Importantly, potent proinflammatory cytokines (tumor necrosis factor and interleukin 1) lead to the conversion of mesenchymal stem cells (MSCs) to inflammatory cancer-associated fibroblasts (CAFs) [135]. Rubenstein, et al. [135] have shown that these inflammation-driven CAFs secrete metastasis-promoting factors that elevate the dispersion, scattering, and migration of breast cancer cells via activation of tumor cell 
receptors that signal through Ras proteins and via $\mathrm{G} \alpha \mathrm{I}$ proteins; the latter receptors were identified as the chemokine receptors CCR2, CCR5, and CXCR1/2. MSCs are thus highly versatile cells with the ability to respond to a spectrum of stimuli and with the potential to influence multiple aspects of breast carcinogenesis.

Cancer-associated fibroblasts (CAFs) are also an important contributor to the inflammatory component of breast cancers. CAFs are the largest population of stromal cells in breast tumors [139] and are considered to represent up to $80 \%$ of stromal fibroblasts. CAFs are phenotypically and metabolically distinct from normal fibroblasts [140-142]. Genetic and/or epigenetic cancer-specific alterations have been observed in CAFs, including defective p53/p21-dependent signaling pathway, low basal levels of p53 and p21, and strong expression of the proliferation markers Ki-67 [143,144]. CAFs are implicated in every stage of cancer from initiation to colonization, and one of the most important roles of CAFs is to mediate cancer inflammation, which is a major driver of metastasis [143]. A proinflammatory gene signature has been identified in CAFs of breast tumors and consists of two chemokines that are chemoattractants for neutrophils and macrophages (CXCL1, and CXCL2), the proinflammatory cytokines IL- $1 \beta$ and IL-6, the proangiogenic gene CYR61, COX-2, and osteopontin (OPN), which is known to affect inflammation, angiogenesis and metastasis $[60,143,145]$. By the secretion of chemokines and cytokines, CAFs attract inflammatory cells including macrophages, monocytes, and neutrophils to the tumor [143]. Activation of CAFs in triple negative breast cancer, for example is associated with expression of CXCL16, which is a monocyte attractant [145]. CAFs can activate the NFKB signaling pathway to evoke a proinflammatory response, and through the secretion of IL-1 $\beta$, IL-6, IL-8, and SDF-1 induce the recruitment of immune cells and influence epithelial behavior [102]. Cytokines from CAFs and from mononuclear inflammatory cells have also been shown to have prognostic significance: a high score of IL-6, and the expression of IL-1 $\beta$ by each stromal cells (CAFs and MICs) was significantly associated with both longer relapse free-survival (RFS) and overall survival (OS) [146]. CAFs thus play an important role in the chronic inflammatory events in breast cancer, influencing the activities of both epithelial cells, immune cells, extracellular matrix and other components of the tumor microenvironment.

\subsection{Chronic Inflammation and the Promotion of Metastatic Disease}

Breast cancer is clearly a systemic disease, and an important consequence of chronic inflammation in breast cancer is the potential for promotion of metastatic disease. This has been emphasized in several publications discussed above and may be associated with proinflammatory activities of multiple cell types including adipocytes [93], MSC [137], and CAFs [143], or from associated immune cells. A very interesting recent study demonstrated a possible mechanism for the promotion of micrometastases by inflammation. It was shown that the systemic inflammatory and immunosuppressive response to surgery triggers the outgrowth of distant immune-controlled tumors in mouse models of dormancy [147]. Panigrahy et al. [148] addressed this concept in a mouse model and demonstrated that the preoperative administration of the anti-inflammatory agent ketorolac (an NSAID) eradicated micrometastases and promoted long-term survival in multiple tumor-resection models. The antitumor effect of ketorolac was T cell-dependent and involved increases in CD4+ and CD8+ cells and a reduction of FOXP3+ cells, which was augmented by immune checkpoint blockade, negated by adjuvant chemotherapy and dependent on inhibition of the COX-1/thromboxane A2 (TXA2) pathway. Thromboxane A2 (TXA2) downstream from COX-1 is a potent vasoconstrictor and induces platelet aggregation, a process that is known to help metastatic tumor seeding and cancer cell survival in the mouse. TXA2 production was decreased with preoperative ketorolac. This study thus provides compelling evidence for the manner in which chronic inflammation in tumors may promote the development of metastatic disease. 


\title{
5. Summary and Conclusions
}

Chronic inflammation may play an important role throughout breast carcinogenesis, influencing the initiation, development and outcome of breast cancer. In early breast carcinogenesis, obesity (a prevalent problem with an incidence of $43 \%$ of women across all age groups [149]) is an important contributor through adipocyte hypertrophy and crownlike structures, especially in the presence of histologic evidence of benign breast disease. Other factors, such as the microbiome, genomic abnormalities and cellular changes, are present in healthy breast tissue with the potential to elicit inflammatory changes. Together, however, the inflammatory processes and changes in normal breast tissue appear to be less than in those of breast cancer, suggesting many of these changes may occur later, or with the transition to malignancy. The importance of chronic inflammation in the development of breast cancer encourages further studies and the identification of new related targets for breast cancer prevention.

Funding: This research was supported by the Intramural Research Program, Center for Cancer Research, National Cancer Institute, National Institutes of Health, Bethesda, MD.

Institutional Review Board Statement: Not applicable.

Informed Consent Statement: Not applicable.

Data Availability Statement: Not applicable.

Conflicts of Interest: The author declares no potential conflict of interest.

\begin{abstract}
Abbreviations
ASA—aspirin; CRP—C-reactive protein; DAMPS—damage-associated-molecular patterns; HMGB1 — high-mobility-group box 1; MAMPS—microbe-associated-molecular patterns; NSAID—nonsteroidal anti-inflammatory drug; NAF—nipple aspirate fluid; PAMPS— pathogen-associated-molecular patterns; PRR — pattern recognition receptors; TLR—tolllike receptors; CLS—crown-like structures; RR-relative risk; CAA—cancer associated adipocytes; $\mathrm{CAF}$ - cancer associated fibroblasts; TNB — triple negative breast cancer; MSCmesenchymal stem cells.
\end{abstract}

\section{References}

1. Balkwill, F.; Mantovani, A. Inflammation and cancer: Back to Virchow? Lancet 2001, 357, 539-545. [CrossRef]

2. Multhoff, G.; Molls, M.; Radons, J. Chronic Inflammation in Cancer Development. Front. Immunol. 2012, 2, 98. [CrossRef] [PubMed]

3. American Cancer Society. Breast Cancer Facts and Figures 2019; American Cancer Society, Inc.: Atlanta, GA, USA, 2020.

4. Gabay, C.; Kushner, I. Acute-Phase Proteins and Other Systemic Responses to Inflammation. N. Engl. J. Med. 1999, 340, 448-454. [CrossRef] [PubMed]

5. Lithgow, D.; Nyamathi, A.; Elashoff, D.; Martinez-Maza, O.; Covington, C. C-reactive protein in nipple as pirate fluid: Relation to women's health factors. Nurs. Res. 2006, 55, 418-425. [CrossRef]

6. $\quad$ Bardia, A.; Olson, J.E.; Vachon, C.M.; Lazovich, D.; Vierkant, R.; Wang, A.H.; Limburg, P.J.; Anderson, K.E.; Cerhan, J.R. Effect of aspirin and other NSAIDs on postmenopausal breast cancer incidence by hormone receptor status: Results from a prospective cohort study. Breast Cancer Res. Treat. 2010, 126, 149-155. [CrossRef] [PubMed]

7. Carter, J.M.; Hoskin, T.L.; Pena, M.A.; Brahmbhatt, R.; Winham, S.J.; Frost, M.H.; Stallings-Mann, M.; Radisky, D.C.; Knutson, K.L.; Visscher, D.W.; et al. Macrophagic "Crown-like Structures" Are Associated with an Increased Risk of Breast Cancer in Benign Breast Disease. Cancer Prev. Res. 2018, 11, 113-119. [CrossRef]

8. Goff, S.L.; Danforth, D.N. The Role of Immune Cells in Breast Tissue and Immunotherapy for the Treatment of Breast Cancer. Clin. Breast Cancer 2021, 21, e63-e73. [CrossRef]

9. Colotta, F.; Allavena, P.; Sica, A.; Garlanda, C.; Mantovani, A. Cancer-related inflammation, the seventh hallmark of cancer: Links to genetic instability. Carcinogenesis 2009, 30, 1073-1081. [CrossRef]

10. Guo, L.; Liu, S.; Zhang, S.; Chen, Q.; Zhang, M.; Quan, P.; Lu, J.; Sun, X. C-reactive protein and risk of breast cancer: A systematic review and meta-analysis. Sci. Rep. 2015, 5, 10508. [CrossRef] 
11. Siemes, C.; Visser, L.E.; Coebergh, J.-W.W.; Splinter, T.A.; Witteman, J.C.; Uitterlinden, A.G.; Hofman, A.; Pols, H.A.; Stricker, B.H. C-Reactive Protein Levels, Variation in the C-Reactive Protein Gene, and Cancer Risk: The Rotterdam Study. J. Clin. Oncol. 2006, 24, 5216-5222. [CrossRef]

12. Reeves, G.K.; Pirie, K.; Beral, V.; Green, J.; Spencer, E.; Bull, D. Cancer incidence and mortality in relation to body mass index in the Million Women Study: Cohort study. BMJ 2007, 335, 1134. [CrossRef]

13. White, A.J.; Nichols, H.B.; Bradshaw, P.T.; Sandler, D.P. Overall and central adiposity and breast cancer risk in the sister study. Cancer 2015, 121, 3700-3708. [CrossRef] [PubMed]

14. Neuhouser, M.L.; Aragaki, A.K.; Prentice, R.L.; Manson, J.E.; Chlebowski, R.; Carty, C.L.; Ochs-Balcom, H.M.; Thomson, C.A.; Caan, B.J.; Tinker, L.F.; et al. Overweight, Obesity, and Postmenopausal Invasive Breast Cancer Risk: A Secondary Analysis of the Women's Health Initiative Randomized Clinical Trials. JAMA Oncol. 2015, 1, 611-621. [CrossRef] [PubMed]

15. Visser, M.; Bouter, L.M.; McQuillan, G.M.; Wener, M.H.; Harris, T.B. Elevated C-reactive protein levels in overweight and obese adults. JAMA 1999, 282, 2131-2135. [CrossRef]

16. Agnoli, C.; Grioni, S.; Pala, V.; Allione, A.; Matullo, G.; Gaetano, C.D.; Tagliabue, G.; Sieri, S.; Krogh, V. Bi-omarkers of inflammation and breast cancer risk: A case-control study nested in the EPIC-Varese cohort. Sci. Rep. 2017, 7, 12708. [CrossRef]

17. Ma, S.; Guo, C.; Sun, C.; Han, T.; Zhang, H.; Qu, G.; Jiang, Y.; Zhou, Q.; Sun, Y. Aspirin Use and Risk of Breast Cancer: A Meta-analysis of Observational Studies from 1989 to 2019. Clin. Breast Cancer 2021. [CrossRef]

18. Bertrand, K.A.; Bethea, T.N.; Gerlovin, H.; Coogan, P.F.; Barber, L.; Rosenberg, L.; Palmer, J.R. Aspirin use and risk of breast cancer in African American women. Breast Cancer Res. 2020, 22, 96. [CrossRef] [PubMed]

19. Hanna, M.; Dumas, I.; Orain, M.; Jacob, S.; Têtu, B.; Sanschagrin, F.; Bureau, A.; Poirier, B.; Diorio, C. Association between expression of inflammatory markers in normal breast tissue and mammographic density among premenopausal and postmenopausal women. Menopause 2017, 24, 524-535. [CrossRef]

20. Yaghjyan, L.; Colditz, G.; Rosner, B.; Tamimi, R.M. Mammographic Breast Density and Subsequent Risk of Breast Cancer in Postmenopausal Women According to the Time Since the Mammogram. Cancer Epidemiol. Biomark. Prev. 2013, 22, $1110-1117$. [CrossRef]

21. Hugo, H.J.; Saunders, C.; Ramsay, R.; Thompson, E.W. New Insights on COX-2 in Chronic Inflammation Driving Breast Cancer Growth and Metastasis. J. Mammary Gland. Biol. Neoplasia 2015, 20, 109-119. [CrossRef]

22. Chew, G.L.; Huo, C.W.; Huang, D.; Hill, P.; Cawson, J.; Frazer, H.; Hopper, J.L.; Haviv, I.; Henderson, M.A.; Britt, K.; et al. Increased COX-2 expression in epithelial and stromal cells of high mammographic density tissues and in a xenograft model of mammographic density. Breast Cancer Res. Treat. 2015, 153, 89-99. [CrossRef]

23. Esbona, K.; Yi, Y.; Saha, S.; Yu, M.; Van Doorn, R.R.; Conklin, M.W.; Graham, D.S.; Wisinski, K.B.; Ponik, S.M.; Eliceiri, K.W.; et al. The Presence of Cyclooxygenase 2, Tumor-Associated Macrophages, and Collagen Alignment as Prognostic Markers for Invasive Breast Carcinoma Patients. Am. J. Pathol. 2018, 188, 559-573. [CrossRef] [PubMed]

24. Chan, P.-C.; Liao, M.-T.; Hsieh, P.-S. The Dualistic Effect of COX-2-Mediated Signaling in Obesity and Insulin Resistance. Int. J. Mol. Sci. 2019, 20, 3115. [CrossRef]

25. Danforth, D.N.; Filie, A.C.; Warner, A.C.; Wright, G.W.; Sun, Z.; Ried, T.; McGowan, C.T.; Prindiville, S.A. Characteristics of breast ducts in normal risk and high-risk women and their relationship to ductal cytologic atypia. Cancer Prev. Res. 2020, 13, 1027-1036. [CrossRef] [PubMed]

26. Degnim, A.C.; Brahmbhatt, R.D.; Radisky, D.C.; Hoskin, T.L.; Stallings-Mann, M.; Laudenschlager, M.; Mansfield, A.; Frost, M.H.; Murphy, L.; Knutson, K.; et al. Immune cell quantitation in normal breast tissue lobules with and without lobulitis. Breast Cancer Res. Treat. 2014, 144, 539-549. [CrossRef]

27. Ruffell, B.; Au, A.; Rugo, H.S.; Esserman, L.J.; Hwang, E.S.; Coussens, L.M. Leukocyte composition of human breast cancer. Proc. Natl. Acad. Sci. USA 2012, 109, 2796-2801. [CrossRef] [PubMed]

28. Hussein, M.R.; I. Hassan, H. Analysis of the mononuclear inflammatory cell infiltrate in the normal breast, benign proliferative breast disease, in situ and infiltrating ductal breast carcinomas: Preliminary observations. J. Clin. Pathol. 2006, 59, 972-977. [CrossRef] [PubMed]

29. Degnim, A.C.; Hoskin, T.L.; Arshad, M.; Frost, M.H.; Winham, S.; Brahmbhatt, R.A.; Pena, A.; Carter, J.M.; Stallings-Mann, M.L.; Murphy, L.M.; et al. Alterations in the Immune Cell Composition in Premalignant Breast Tissue that Precede Breast Cancer Development. Clin. Cancer Res. 2017, 23, 3945-3952. [CrossRef] [PubMed]

30. Wozniak, S.E.; Gee, L.L.; Wachtel, M.S.; Frezza, E.E. Adipose tissue: The new endocrine organ? A review article. Dig. Dis. Sci. 2009, 54, 1847-1856. [CrossRef]

31. Coelho, M.; Oliveira, T.; Fernandes, R. State of the art paper Biochemistry of adipose tissue: An endocrine organ. Arch. Med. Sci. 2013, 9, 191-200. [CrossRef] [PubMed]

32. Asterholm, I.W.; Tao, C.; Morley, T.S.; Wang, Q.; Delgado-Lopez, F.; Wang, Z.; Scherer, P.E. Adipocyte Inflammation Is Essential for Healthy Adipose Tissue Expansion and Remodeling. Cell Metab. 2014, 20, 103-118. [CrossRef]

33. Mancuso, P. The role of adipokines in chronic inflammation. ImmunoTargets Ther. 2016, 5, 47-56. [CrossRef] [PubMed]

34. Ouchi, N.; Parker, J.L.; Lugus, J.J.; Walsh, K. Adipokines in inflammation and metabolic disease. Nat. Rev. Immunol. 2011, 11, 85-97. [CrossRef] [PubMed]

35. Laskin, D.L.; Sunil, V.R.; Gardner, C.R.; Laskin, J.D. Macrophages and tissue injury: Agents of defense or destruction? Annu. Rev. Pharm. Toxicol. 2011, 51, 267-288. [CrossRef] 
36. Quail, D.F.; Dannenberg, A.J. The obese adipose tissue microenvironment in cancer development and progression. Nat. Rev. Endocrinol. 2019, 15, 139-154. [CrossRef]

37. Vandeweyer, E.; Hertens, D. Quantification of glands and fat in breast tissue: An experimental determination. Ann. Anat. 2002, 184, 181-184. [CrossRef]

38. Kang, T.; Yau, C.; Wong, C.K.; Sanborn, J.Z.; Newton, Y.; Vaske, C.; Benz, S.C.; Krings, G.; Camarda, R.; Henry, J.E.; et al. A risk-associated Active transcriptome phenotype expressed by histologically normal human breast tissue and linked to a protumorigenic adipocyte population. Breast Cancer Res. 2020, 22, 81. [CrossRef]

39. Sun, X.; Casbas-Hernandez, P.; Bigelow, C.; Makowski, L.; Joseph Jerry, D.; Smith Schneider, S.; Troester, M.A. Normal breast tissue of obese women is enriched for macrophage markers and macrophage-associated gene expression. Breast Cancer Res. Treat. 2012, 131, 1003-1012. [CrossRef]

40. Dalamaga, M. Resistin as a biomarker linking obesity and inflammation to cancer: Potential clinical perspectives. Biomark. Med. 2014, 8, 107-118. [CrossRef]

41. Andò, S.; Gelsomino, L.; Panza, S.; Giordano, C.; Bonofiglio, D.; Barone, I.; Catalano, S. Obesity, Leptin and Breast Cancer: Epidemiological Evidence and Proposed Mechanisms. Cancers 2019, 11, 62. [CrossRef] [PubMed]

42. Schäffler, A.; Schölmerich, J. Innate immunity and adipose tissue biology. Trends Immunol. 2010, 31, 228-235. [CrossRef]

43. Morris, P.G.; Hudis, C.A.; Giri, D.; Morrow, M.; Falcone, D.J.; Zhou, X.K.; Du, B.; Brogi, E.; Crawford, C.B.; Kopelovich, L.; et al. Inflammation and increased aromatase expression occur in the breast tissue of obese women with breast cancer. Cancer Prev. Res. 2011, 4, 1021-1029. [CrossRef] [PubMed]

44. Olefsky, J.M.; Glass, C.K. Macrophages, Inflammation, and Insulin Resistance. Annu. Rev. Physiol. 2010, 72, 219-246. [CrossRef]

45. Kopp, A.; Buechler, C.; Neumeier, M.; Weigert, J.; Aslanidis, C.; Schölmerich, J.; Schäffler, A. Innate immunity and adipocyte function: Ligand-specific activation of multiple Toll-like receptors modulates cytokine, adipokine, and chemokine secretion in adipocytes. Obesity 2009, 17, 648-656. [CrossRef] [PubMed]

46. Savini, I.; Catani, M.V.; Evangelista, D.; Gasperi, V.; Avigliano, L. Obesity-associated oxidative stress: Strategies finalized to improve redox state. Int. J. Mol. Sci. 2013, 14, 10497-10538. [CrossRef] [PubMed]

47. Lengyel, E.; Makowski, L.; DiGiovanni, J.; Kolonin, M.G. Cancer as a Matter of Fat: The Crosstalk between Adipose Tissue and Tumors. Trends Cancer 2018, 4, 374-384. [CrossRef]

48. Enomoto, T.; Ohashi, K.; Shibata, R.; Higuchi, A.; Maruyama, S.; Izumiya, Y.; Walsh, K.; Murohara, T.; Ouchi, N. Adipolin/C1qdc2/CTRP12 Protein Functions as an Adipokine That Improves Glucose Metabolism. J. Biol. Chem. 2011, 286, 34552-34558. [CrossRef]

49. Escoté, X.; Gómez-Zorita, S.; López-Yoldi, M.; Milton-Laskibar, I.; Fernández-Quintela, A.; Martínez, J.A.; Moreno-Aliaga, M.J.; Portillo, M.P. Role of Omentin, Vaspin, Cardiotrophin-1, TWEAK and NOV/CCN3 in Obesity and Diabetes Development. Int. J. Mol. Sci. 2017, 18, 1770. [CrossRef]

50. Ouchi, N.; Higuchi, A.; Ohashi, K.; Oshima, Y.; Gokce, N.; Shibata, R.; Akasaki, Y.; Shimono, A.; Walsh, K. Sfrp5 Is an AntiInflammatory Adipokine That Modulates Metabolic Dysfunction in Obesity. Science 2010, 329, 454-457. [CrossRef] [PubMed]

51. Van Kruijsdijk, R.C.M.; Van Der Wall, E.; Visseren, F. Obesity and Cancer: The Role of Dysfunctional Adipose Tissue. Cancer Epidemiol. Biomark. Prev. 2009, 18, 2569-2578. [CrossRef]

52. Mullooly, M.; Yang, H.P.; Falk, R.T.; Nyante, S.J.; Cora, R.; Pfeiffer, R.M.; Radisky, D.C.; Visscher, D.W.; Hartmann, L.C.; Carter, J.M.; et al. Relationship between crown-like structures and sex-steroid hormones in breast adipose tissue and serum among postmenopausal breast cancer patients. Breast Cancer Res. 2017, 19, 8. [CrossRef]

53. Iyengar, N.M.; Morris, P.G.; Zhou, X.K.; Gucalp, A.; Giri, D.; Harbus, M.D.; Falcone, D.J.; Krasne, M.; Vahdat, L.T.; Subbaramaiah, K.; et al. Menopause Is a Determinant of Breast Adipose Inflammation. Cancer Prev. Res. 2015, 8, 349-358. [CrossRef] [PubMed]

54. Brown, K.A.; Iyengar, N.M.; Zhou, X.K.; Gucalp, A.; Subbaramaiah, K.; Wang, H.; Giri, D.D.; Morrow, M.; Falcone, D.J.; Wendel, N.K.; et al. Meno-pause Is a Determinant of Breast Aromatase Expression and Its Associations With BMI, Inflammation, and Systemic Markers. J. Clin. Endocrinol. Metab. 2017, 102, 1692-1701. [CrossRef] [PubMed]

55. Greenlee, H.; Shi, Z.; Hibshoosh, H.; Giri, D.D.; Ahmed, A.; Williams, S.; Falcone, D.J.; Winston, L.A.; Zhou, X.K.; Hudis, C.A.; et al. Obesity-associated Breast Inflammation among Hispanic/Latina Breast Cancer Patients. Cancer Prev. Res. 2019, 12, 21-30. [CrossRef] [PubMed]

56. Springer, N.L.; Iyengar, N.M.; Bareja, R.; Verma, A.; Jochelson, M.S.; Giri, D.D.; Zhou, X.K.; Elemento, O.; Dannenberg, A.J.; Fischbach, C. Obesity-Associated Extracellular Matrix Remodeling Promotes a Macrophage Phenotype Similar to TumorAssociated Macrophages. Am. J. Pathol. 2019, 189, 2019-2035. [CrossRef]

57. Subbaramaiah, K.; Howe, L.R.; Bhardwaj, P.; Du, B.; Gravaghi, C.; Yantiss, R.K.; Zhou, X.K.; Blaho, V.A.; Hla, T.; Yang, P.; et al. Obesity is associated with inflammation and elevated aromatase expression in the mouse mammary gland. Cancer Prev. Res. 2011, 4, 329-346. [CrossRef]

58. Bhowmick, N.A.; Neilson, E.G.; Moses, H.L. Stromal fibroblasts in cancer initiation and progression. Nat. Cell Biol. 2004, 432, 332-337. [CrossRef]

59. Parsonage, G.; Filer, A.D.; Haworth, O.; Nash, G.B.; Rainger, G.E.; Salmon, M.; Buckley, C.D. A stromal address code defined by fibroblasts. Trends Immunol. 2005, 26, 150-156. [CrossRef] 
60. Erez, N.; Truitt, M.; Olson, P.; Arron, S.T.; Hanahan, D. Cancer-Associated Fibroblasts Are Activated in Incipient Neoplasia to Orchestrate Tumor-Promoting Inflammation in an NF-kappaB-Dependent Manner. Cancer Cell 2010, 17, 135-147. [CrossRef] [PubMed]

61. Strell, C.; Rundqvist, H.; Östman, A. Fibroblasts-A key host cell type in tumor initiation, progression, and metastasis. Upsala J. Med. Sci. 2012, 117, 187-195. [CrossRef] [PubMed]

62. O'Connor, H.; Mac Sharry, J.; Bueso, Y.F.; Lindsay, S.; Kavanagh, E.L.; Tangney, M.; Clyne, M.; Saldova, R.; McCann, A. Resident bacteria in breast cancer tissue: Pathogenic agents or harmless commensals? Discov. Med. 2018, 26, 93-102.

63. Urbaniak, C.; Cummins, J.; Brackstone, M.; Macklaim, J.M.; Gloor, G.; Baban, C.K.; Scott, L.; O’Hanlon, D.M.; Burton, J.; Francis, K.P.; et al. Microbiota of Human Breast Tissue. Appl. Environ. Microbiol. 2014, 80, 3007-3014. [CrossRef]

64. Hieken, T.J.; Chen, J.; Hoskin, T.L.; Walther-Antonio, M.; Johnson, S.; Ramaker, S.; Xiao, J.; Radisky, D.C.; Knutson, K.L.; Kalari, K.; et al. The Microbiome of Aseptically Collected Human Breast Tissue in Benign and Malignant Disease. Sci. Rep. 2016, 6, 30751. [CrossRef]

65. Meng, S.; Chen, B.; Yang, J.; Wang, J.; Zhu, D.; Meng, Q.; Zhang, L. Study of Microbiomes in Aseptically Col-lected Samples of Human Breast Tissue Using Needle Biopsy and the Potential Role of in situ Tissue Microbiomes for Promoting Malignancy. Front. Oncol. 2018, 8, 318. [CrossRef]

66. Roy, S.; Trinchieri, G. Microbiota: A key orchestrator of cancer therapy. Nat. Rev. Cancer 2017, 17, 271-285. [CrossRef]

67. Xuan, C.; Shamonki, J.M.; Chung, A.; DiNome, M.; Chung, M.; Sieling, P.A.; Lee, D.J. Microbial Dysbiosis Is Associated with Human Breast Cancer. PLoS ONE 2014, 9, e83744. [CrossRef]

68. Rakoff-Nahoum, S.; Medzhitov, R. Toll-like receptors and cancer. Nat. Rev. Cancer 2008, 9, 57-63. [CrossRef]

69. Mezouar, S.; Chantran, Y.; Michel, J.; Fabre, A.; Dubus, J.; Leone, M.; Sereme, Y.; Mege, J.; Ranque, S.; Des-nues, B.; et al. Micreobiome and the immune system: From a healthy steady-state to allergy associated disruption. Hum. Microbiome J. 2018, 10, 11-20. [CrossRef]

70. Karin, M.; Lawrence, T.; Nizet, V. Innate immunity gone awry: Linking microbial infections to chronic inflammation and cancer. Cell 2006, 124, 823-835. [CrossRef]

71. Chan, A.A.; Bashir, M.; Rivas, M.N.; Duvall, K.; Sieling, P.A.; Pieber, T.R.; Vaishampayan, P.A.; Love, S.M.; Lee, D.J. Characterization of the microbiome of nipple aspirate fluid of breast cancer survivors. Sci. Rep. 2016, 6, 28061. [CrossRef]

72. Urbaniak, C.; Gloor, G.B.; Brackstone, M.; Scott, L.; Tangney, M.; Reid, G. The Microbiota of Breast Tissue and Its Association with Breast Cancer. Appl. Environ. Microbiol. 2016, 82, 5039-5048. [CrossRef]

73. Kosaka, A.; Yan, H.; Ohashi, S.; Gotoh, Y.; Sato, A.; Tsutsui, H.; Kaisho, T.; Toda, T.; Tsuji, N.M. Lactococcus lactis subsp. cremoris FC triggers IFN- $\gamma$ production from NK and T cells via IL-12 and IL-18. Int. Immunopharmacol. 2012, 14, 729-733. [CrossRef]

74. LeBlanc, A.D.M.D.; Matar, C.; Thériault, C.; Perdigón, G. Effects of milk fermented by Lactobacillus helveticus R389 on immune cells associated to mammary glands in normal and a breast cancer model. Immunobiology 2005, 210, 349-358. [CrossRef]

75. Eslami-S, Z.; Majidzadeh-A, K.; Halvaei, S.; Babapirali, F.; Esmaeili, R. Microbiome and Breast Cancer: New Role for an Ancient Population. Front. Oncol. 2020, 10, 120. [CrossRef]

76. Shively, C.A.; Register, T.C.; Appt, S.E.; Clarkson, T.B.; Uberseder, B.; Clear, K.Y.; Wilson, A.S.; Chiba, A.; Tooze, J.A.; Cook, K.L. Consumption of Mediterranean versus Western Diet Leads to Distinct Mammary Gland Microbiome Populations. Cell Rep. 2018, 25, 47-56.e3. [CrossRef]

77. Yu, L.; Wang, L.; Chen, S. Endogenous toll-like receptor ligands and their biological significance. J. Cell. Mol. Med. 2010, 14, 2592-2603. [CrossRef]

78. Ferguson, D.; Anderson, T.J. Morphological evaluation of cell turnover in relation to the menstrual cycle in the "resting" human breast. Br. J. Cancer 1981, 44, 177-181. [CrossRef]

79. Bell, C.W.; Jiang, W.; Reich, C.F., 3rd; Pisetsky, D.S. The extracellular release of HMGB1 during apoptotic cell death. Am. J. Physiol. Cell Physiol. 2006, 291, C1318-C1325. [CrossRef]

80. Danforth, D.N. Genomic Changes in Normal Breast Tissue in Women at Normal Risk or at High Risk for Breast Cancer. Breast Cancer Basic Clin. Res. 2016, 10, 109-146. [CrossRef]

81. Rodier, F.; Coppe, J.P.; Patil, C.K.; Hoeijmakers, W.A.; Munoz, D.P.; Raza, S.R.; Freund, A.; Campeau, E.; Davalos, A.R.; Campisi, J. Persistent DNA damage signalling triggers senescence-associated inflammatory cytokine secretion. Nat. Cell Biol. 2009, 11, 973-979. [CrossRef]

82. Kamal, R.M.; Hamed, S.T.; Salem, D.S. Classification of inflammatory breast disorders and step by step diagnosis. Breast J. 2009, 15, 367-380. [CrossRef]

83. Degnim, A.C.; Visscher, D.W.; Hoskin, T.L.; Frost, M.H.; Vierkant, R.; Vachon, C.M.; Pankratz, V.S.; Radisky, D.C.; Hartmann, L.C. Histologic findings in normal breast tissues: Comparison to reduction mammaplasty and benign breast disease tissues. Breast Cancer Res. Treat. 2011, 133, 169-177. [CrossRef]

84. Mohammed, Z.M.; Going, J.J.; Edwards, J.; Elsberger, B.; Doughty, J.C.; McMillan, D.C. The relationship between components of tumour inflammatory cell infiltrate and clinicopathological factors and survival in patients with primary operable invasive ductal breast cancer. Br. J. Cancer 2012, 107, 864-873. [CrossRef]

85. Wang, J.; Cai, D.; Ma, B.; Wu, G.; Wu, J. Skewing the Balance of Regulatory T-Cells and T-Helper 17 Cells in Breast Cancer Patients. J. Int. Med. Res. 2011, 39, 691-701. [CrossRef] 
86. Egelston, C.A.; Avalos, C.; Tu, T.Y.; Simons, D.L.; Jimenez, G.; Jung, J.Y.; Melstrom, L.; Margolin, K.; Yim, J.H.; Kruper, L.; et al. Human breast tumor-infiltrating CD8+ T cells retain polyfunctionality despite PD-1 expression. Nat. Commun. 2018, 9, 4297. [CrossRef]

87. Chan, C.C.; Damen, M.; Alarcon, P.C.; Sanchez-Gurmaches, J.; Divanovic, S. Inflammation and Immunity: From an Adipocyte's Perspective. J. Interferon Cytokine Res. 2019, 39, 459-471. [CrossRef]

88. Gilbert, C.A.; Slingerland, J.M. Cytokines, Obesity, and Cancer: New Insights on Mechanisms Linking Obesity to Cancer Risk and Progression. Annu. Rev. Med. 2013, 64, 45-57. [CrossRef] [PubMed]

89. Ohashi, K.; Shibata, R.; Murohara, T.; Ouchi, N. Role of anti-inflammatory adipokines in obesity-related diseases. Trends Endocrinol. Metab. 2014, 25, 348-355. [CrossRef]

90. Osborn, O.; Olefsky, J.M. The cellular and signaling networks linking the immune system and metabolism in disease. Nat. Med. 2012, 18, 363-374. [CrossRef] [PubMed]

91. Berger, N.A. Crown-like Structures in Breast Adipose Tissue from Normal Weight Women: Important Impact. Cancer Prev. Res. 2017, 10, 223-225. [CrossRef]

92. Wu, Q.; Li, B.; Li, Z.; Li, J.; Sun, S.; Sun, S. Cancer-associated adipocytes: Key players in breast cancer progression. J. Hematol. Oncol. 2019, 12, 95. [CrossRef] [PubMed]

93. Tokumaru, Y.; Oshi, M.; Katsuta, E.; Yan, L.; Huang, J.L.; Nagahashi, M.; Matsuhashi, N.; Futamura, M.; Yo-shida, K.; Takabe, K. Intratumoral Adipocyte-High Breast Cancer Enrich for Metastatic and Inflamma-tion-Related Pathways but Associated with Less Cancer Cell Proliferation. Int. J. Mol. Sci. 2020, 21, 5744. [CrossRef]

94. Rybinska, I.; Agresti, R.; Trapani, A.; Tagliabue, E.; Triulzi, T. Adipocytes in Breast Cancer, the Thick and the Thin. Cells 2020, 9 , 560. [CrossRef]

95. Brown, J.M.; Hazen, S.L. Microbial modulation of cardiovascular disease. Nat. Rev. Genet. 2018, 16, 171-181. [CrossRef]

96. Wang, J.; Chen, W.-D.; Wang, Y.-D. The Relationship between Gut Microbiota and Inflammatory Diseases: The Role of Macrophages. Front. Microbiol. 2020, 11, 1065. [CrossRef] [PubMed]

97. Locati, M.; Mantovani, A.; Sica, A. Macrophage activation and polarization as an adaptive component of innate immunity. In Advances in Immunology; Elsevier: Amsterdam, The Netherlands, 2013; Volume 120, pp. 163-184.

98. Doni, A.; D'Amico, G.; Morone, D.; Mantovani, A.; Garlanda, C. Humoral innate immunity at the crossroad between microbe and matrix recognition: The role of PTX3 in tissue damage. Semin. Cell Dev. Biol. 2017, 61, 31-40. [CrossRef]

99. Bernardo, M.E.; Fibbe, W.E. Mesenchymal Stromal Cells: Sensors and Switchers of Inflammation. Cell Stem Cell 2013, 13, $392-402$. [CrossRef] [PubMed]

100. Li, W.; Ren, G.; Huang, Y.; Su, J.; Han, Y.; Li, J.; Chen, X.; Cao, K.; Chen, Q.; Shou, P.; et al. Mesenchymal stem cells: A double-edged sword in regulating immune responses. Cell Death Differ. 2012, 19, 1505-1513. [CrossRef]

101. Weiss, A.R.R.; Dahlke, M.H. Immunomodulation by Mesenchymal Stem Cells (MSCs): Mechanisms of Action of Living, Apoptotic, and Dead MSCs. Front. Immunol. 2019, 10, 1191. [CrossRef] [PubMed]

102. Eiro, N.; Cid, S.; Fraile, M.; Cabrera, J.R.; Gonzalez, L.O.; Vizoso, F.J. Analysis of the Gene Expression Profile of Stromal Pro-Tumor Factors in Cancer-Associated Fibroblasts from Luminal Breast Carcinomas. Diagnostics 2020, 10, 865. [CrossRef]

103. Servais, C.; Erez, N. From sentinel cells to inflammatory culprits: Cancer-associated fibroblasts in tumour-related inflammation. J. Pathol. 2013, 229, 198-207. [CrossRef]

104. Houthuijzen, J.M.; Jonkers, J. Cancer-associated fibroblasts as key regulators of the breast cancer tumor microenvironment. Cancer Metastasis Rev. 2018, 37, 577-597. [CrossRef]

105. Roh, J.S.; Sohn, D.H. Damage-Associated Molecular Patterns in Inflammatory Diseases. Immune Netw. 2018, 18, e27. [CrossRef] [PubMed]

106. Hernandez, C.; Huebener, P.; Schwabe, R.F. Damage-associated molecular patterns in cancer: A double-edged sword. Oncogene 2016, 35, 5931-5941. [CrossRef]

107. Bianchi, M.E. DAMPs, PAMPs and alarmins: All we need to know about danger. J. Leukoc. Biol. 2007, 81, 1-5. [CrossRef]

108. Mills, K.H.G. TLR-dependent T cell activation in autoimmunity. Nat. Rev. Immunol. 2011, 11, 807-822. [CrossRef]

109. Qiu, S.-Q.; Waaijer, S.J.H.; Zwager, M.C.; De Vries, E.G.E.; Van Der Vegt, B.; Schröder, C.P. Tumor-associated macrophages in breast cancer: Innocent bystander or important player? Cancer Treat. Rev. 2018, 70, 178-189. [CrossRef] [PubMed]

110. Yang, L.; Qi, Y.; Hu, J.; Tang, L.; Zhao, S.; Shan, B. Expression of Th17 cells in breast cancer tissue and its association with clinical parameters. Cell Biochem. Biophys. 2012, 62, 153-159. [CrossRef]

111. Bastid, J.; Bonnefoy, N.; Eliaou, J.-F.; Bensussan, A. Lymphocyte-derived interleukin-17A adds another brick in the wall of inflammation-induced breast carcinogenesis. OncoImmunology 2014, 3, e28273. [CrossRef]

112. Eftekhari, R.; Esmaeili, R.; Mirzaei, R.; Bidad, K.; De Lima, S.; Ajami, M.; Shirzad, H.; Hadjati, J.; Majidzadeh-A, K. Study of the tumor microenvironment during breast cancer progression. Cancer Cell Int. 2017, 17, 123. [CrossRef]

113. Huang, Y.; Ma, C.; Zhang, Q.; Ye, J.; Wang, F.; Zhang, Y.; Hunborg, P.; Varvares, M.A.; Hoft, D.F.; Hsueh, E.C.; et al. CD4+ and CD8+ T cells have opposing roles in breast cancer progression and outcome. Oncotarget 2015, 6, 17462-17478. [CrossRef]

114. DeNardo, D.G.; Coussens, L.M. Inflammation and breast cancer. Balancing immune response: Crosstalk between adaptive and innate immune cells during breast cancer progression. Breast Cancer Res. 2007, 9, 212. [CrossRef]

115. Carvalho, M.I.; Pires, I.; Prada, J.; Queiroga, F. A Role for T-Lymphocytes in Human Breast Cancer and in Canine Mammary Tumors. BioMed Res. Int. 2014, 2014, 1-11. [CrossRef] [PubMed] 
116. Brady, N.J.; Chuntova, P.; Schwertfeger, K.L. Macrophages: Regulators of the Inflammatory Microenvironment during Mammary Gland Development and Breast Cancer. Mediat. Inflamm. 2016, 2016, 4549676. [CrossRef] [PubMed]

117. Mantovani, A.; Marchesi, F.; Malesci, A.; Laghi, L.; Allavena, P. Tumour-associated macrophages as treatment targets in oncology. Nat. Rev. Clin. Oncol. 2017, 14, 399-416. [CrossRef] [PubMed]

118. Mantovani, A.; Sozzani, S.; Locati, M.; Allavena, P.; Sica, A. Macrophage polarization: Tumor-associated macrophages as a paradigm for polarized M2 mononuclear phagocytes. Trends Immunol. 2002, 23, 549-555. [CrossRef]

119. Miligy, I.; Mohan, P.; Gaber, A.; Aleskandarany, M.A.; Nolan, C.C.; Diez-Rodriguez, M.; Mukherjee, A.; Chapman, C.; Ellis, I.O.; Green, A.R.; et al. Prognostic significance of tumour infiltrating B lymphocytes in breast ductal carcinoma in situ. Histopathology 2017, 71, 258-268. [CrossRef]

120. Elkabets, M.; Gifford, A.M.; Scheel, C.; Nilsson, B.; Reinhardt, F.; Bray, M.A.; Carpenter, A.E.; Jirström, K.; Magnusson, K.; Ebert, B.L.; et al. Human tumors instigate granulin-expressing hematopoietic cells that promote malignancy by activating stromal fibroblasts in mice. J. Clin. Investig. 2011, 121, 784-799. [CrossRef]

121. Agresti, R.; Meneghini, E.; Baili, P.; Minicozzi, P.; Turco, A.; Cavallo, I.; Funaro, F.; Amash, H.; Berrino, F.; Tagliabue, E.; et al. Association of adiposity, dysmetabolisms, and inflammation with aggressive breast cancer subtypes: A cross-sectional study. Breast Cancer Res. Treat. 2016, 157, 179-189. [CrossRef]

122. Hong, T.; Liu, A.; Cai, D.; Zhang, Y.; Hua, D.; Hang, X.; Wu, X. Preoperative Serum C-Reactive Protein Levels and Early Breast Cancer by BMI and Menopausal Status. Cancer Investig. 2013, 31, 279-285. [CrossRef]

123. McAndrew, N.P.; Bottalico, L.; Mesaros, C.; Blair, I.A.; Tsao, P.Y.; Rosado, J.M.; Ganguly, T.; Song, S.J.; Gimotty, P.A.; Mao, J.J.; et al. Effects of systemic inflammation on relapse in early breast cancer. NPJ Breast Cancer 2021, 7, 1-10. [CrossRef] [PubMed]

124. Gupta, A.; Oyekunle, T.; Salako, O.; Daramola, A.; Alatise, O.; Ogun, G.; Adeniyi, A.; Deveaux, A.; Saraiya, V.; Hall, A.; et al. Association of high-sensitivity Creactive protein and odds of breast cancer by molecular subtype: Analysis of the MEND study. Oncotarget 2021, 12, 1230-1242. [CrossRef]

125. Rutkowski, M.R.; Stephen, T.L.; Svoronos, N.; Allegrezza, M.J.; Tesone, A.J.; Perales-Puchalt, A.; Brencicova, E.; Escovar-Fadul, X.; Nguyen, J.M.; Cadungog, M.G.; et al. Microbially Driven TLR5-Dependent Signaling Governs Distal Malignant Progression through Tumor-Promoting Inflammation. Cancer Cell 2015, 27, 27-40. [CrossRef] [PubMed]

126. Li, S.; Bi, Y.; Han, M.; Xu, X.; Jiang, M.; Xu, J. Lipopolysaccharide induces inflammation and facilitates lung metastasis in a breast cancer model via the prostaglandin E2-EP2 pathway. Mol. Med. Rep. 2015, 11, 4454-4462. [CrossRef]

127. Chen, C.-J.; Kono, H.; Golenbock, D.; Reed, G.; Akira, S.; Rock, K.L. Identification of a key pathway required for the sterile inflammatory response triggered by dying cells. Nat. Med. 2007, 13, 851-856. [CrossRef] [PubMed]

128. Grivennikov, S.I.; Greten, F.; Karin, M. Immunity, Inflammation, and Cancer. Cell 2010, 140, 883-899. [CrossRef] [PubMed]

129. Apetoh, L.; Ghiringhelli, F.; Tesniere, A.; Obeid, M.; Ortiz, C.; Criollo, A.; Mignot, G.; Maiuri, M.C.; Ullrich, E.; Saulnier, P.; et al. Toll-like receptor 4-dependent contribution of the immune system to anticancer chemotherapy and radiotherapy. Nat. Med. 2007, 13, 1050-1059. [CrossRef] [PubMed]

130. Chiba, S.; Baghdadi, M.; Akiba, H.; Yoshiyama, H.; Kinoshita, I.; Dosaka-Akita, H.; Fujioka, Y.; Ohba, Y.; Gorman, J.V.; Colgan, J.; et al. Tumor-infiltrating DCs suppress nucleic acidmediated innate immune responses through interactions between the receptor TIM-3 and the alarmin HMGBN1. Nat. Immunol. 2012, 13, 832-842. [CrossRef]

131. Gilmore, T.D.; Herscovitch, M. Inhibitors of NF-kappaB signaling: 785 and counting. Oncogene 2006, 25, 6887-6899. [CrossRef]

132. Zhao, C.; Wu, M.; Zeng, N.; Xiong, M.; Hu, W.; Lv, W.; Yi, Y.; Zhang, Q.; Wu, Y. Cancer-associated adipocytes: Emerging supporters in breast cancer. J. Exp. Clin. Cancer Res. 2020, 39, 156. [CrossRef]

133. Cha, Y.J.; Kim, E.-S.; Koo, J.S. Tumor-associated macrophages and crown-like structures in adipose tissue in breast cancer. Breast Cancer Res. Treat. 2018, 170, 15-25. [CrossRef] [PubMed]

134. Koru-Sengul, T.; Santander, A.M.; Miao, F.; Sanchez, L.G.; Jorda, M.; Glück, S.; Ince, T.A.; Nadji, M.; Chen, Z.; Penichet, M.L.; et al. Breast cancers from black women exhibit higher numbers of immunosuppressive macrophages with proliferative activity and of crown-like structures associated with lower survival compared to non-black Latinas and Caucasians. Breast Cancer Res. Treat. 2016, 158, 113-126. [CrossRef] [PubMed]

135. Rubinstein-Achiasaf, L.; Morein, D.; Ben-Yaakov, H.; Liubomirski, Y.; Meshel, T.; Elbaz, E.; Dorot, O.; Pichinuk, E.; Gershovits, M.; Weil, M.; et al. Persistent Inflammatory Stimulation Drives the Conver-sion of MSCs to Inflammatory CAFs That Promote Pro-Metastatic Characteristics in Breast Cancer Cells. Cancers 2021, 13, 1472.

136. Meirelles, L.D.S.; Chagastelles, P.C.; Nardi, N.B. Mesenchymal stem cells reside in virtually all postnatal organs and tissues. J. Cell Sci. 2006, 119 Pt 11, 2204-2213. [CrossRef]

137. El-Haibi, C.P.; Karnoub, A.E. Mesenchymal Stem Cells in the Pathogenesis and Therapy of Breast Cancer. J. Mammary Gland. Biol. Neoplasia 2010, 15, 399-409. [CrossRef]

138. Ren, G.; Zhang, L.; Zhao, X.; Xu, G.; Zhang, Y.; Roberts, A.I.; Zhao, R.C.; Shi, Y. Mesenchymal stem cell-mediated immunosuppression occurs via concerted action of chemokines and nitric oxide. Cell Stem Cell 2008, 2, 141-150. [CrossRef]

139. Lappano, R.; Rigiracciolo, D.C.; Belfiore, A.; Maggiolini, M.; De Francesco, E.M. Cancer associated fibroblasts: Role in breast cancer and potential as therapeutic targets. Expert Opin. Ther. Targets 2020, 24, 559-572. [CrossRef]

140. Esquivel-Velázquez, M.; Ostoa-Saloma, P.; Palacios-Arreola, M.I.; Castro, K.E.N.; Castro, J.I.; Morales-Montor, J. The Role of Cytokines in Breast Cancer Development and Progression. J. Interferon Cytokine Res. 2015, 35, 1-16. [CrossRef] 
141. Aboussekhra, A. Role of cancer-associated fibroblasts in breast cancer development and prognosis. Int. J. Dev. Biol. 2011, 55, 841-849. [CrossRef]

142. De Wever, O.; Demetter, P.; Mareel, M.; Bracke, M. Stromal myofibroblasts are drivers of invasive cancer growth. Int. J. Cancer 2008, 123, 2229-2238. [CrossRef] [PubMed]

143. Balachander, G.M.; Talukdar, P.M.; Debnath, M.; Rangarajan, A.; Chatterjee, K. Inflammatory Role of Cancer-Associated Fibroblasts in Invasive Breast Tumors Revealed Using a Fibrous Polymer Scaffold. ACS Appl. Mater. Interfaces 2018, 10, 33814-33826. [CrossRef] [PubMed]

144. Hawsawi, N.M.; Ghebeh, H.; Hendrayani, S.F.; Tulbah, A.; Al-Eid, M.; Al-Tweigeri, T.; Ajarim, D.; Alaiya, A.; Dermime, S.; Aboussekhra, A. Breast carcinoma-associated fibroblasts and their counterparts display neoplastic-specific changes. Cancer Res. 2008, 68, 2717-2725. [CrossRef] [PubMed]

145. Allaoui, R.; Bergenfelz, C.; Mohlin, S.; Hagerling, C.; Salari, K.; Werb, Z.; Anderson, R.L.; Ethier, S.P.; Jirström, K.; Påhlman, S.; et al. Cancer-associated fibroblast-secreted CXCL16 attracts monocytes to promote stroma activation in triple-negative breast cancers. Nat. Commun. 2016, 7, 13050. [CrossRef] [PubMed]

146. Fernandez-Garcia, B.; Eiro, N.; Miranda, M.A.; Cid, S.; González, L.O.; Domínguez, F.; Vizoso, F.J. Prognostic significance of inflammatory factors expression by stroma from breast carcinomas. Carcinogenesis 2016, 37, 768-776. [CrossRef] [PubMed]

147. Krall, J.A.; Reinhardt, F.; Mercury, O.A.; Pattabiraman, D.R.; Brooks, M.W.; Dougan, M.; Lambert, A.W.; Bierie, B.; Ploegh, H.L.; Dougan, S.K.; et al. The systemic response to surgery triggers the outgrowth of distant immune-controlled tumors in mouse models of dormancy. Sci. Transl. Med. 2018, 10, eaan3464. [CrossRef] [PubMed]

148. Panigrahy, D.; Gartung, A.; Yang, J.; Yang, H.; Gilligan, M.M.; Sulciner, M.L.; Bhasin, S.S.; Bielenberg, D.R.; Chang, J.; Schmidt, B.A.; et al. Preoperative stimulation of resolution and inflammation blockade eradicates micrometastases. J. Clin. Investig. 2019, 129, 2964-2979. [CrossRef]

149. Hales, C.M.; Carroll, M.D.; Fryar, C.D.; Ogden, C.L. Prevalence of Obesity among Adults and Youth: United States, 2015-2016; NCHS Data Brief Series; DHHS Publication: Melbourne, VIC, Australia, 2017; Volume 219, pp. 1-8. 